Article

\title{
Oxygen and Carbon Stable Isotope Composition of Cretaceous to Pliocene Calcareous Paleosols in the Tian Shan Region (Central Asia): Controlling Factors and Paleogeographic Implications
}

\author{
Marc Jolivet ${ }^{1, *}$, Philippe Boulvais ${ }^{1}$, Laurie Barrier ${ }^{2}$, Cécile Robin ${ }^{1}$, Gloria Heilbronn ${ }^{3}$, \\ Julie Ledoyen ${ }^{1}$, Quentin Ventroux ${ }^{1}$, Yingying Jia ${ }^{4}$, Zhaojie Guo ${ }^{5}$ and Elena A. Bataleva ${ }^{6}$ \\ 1 Géosciences Rennes, Université de Rennes, CNRS, UMR 6118, F-35000 Rennes, France; \\ philippe.boulvais@univ-rennes1.fr (P.B.); cecile.robin@univ-rennes1.fr (C.R.); \\ julie.ledoyen@univ-rennes1.fr (J.L.); quentin.ventroux@univ-rennes1.fr (Q.V.) \\ 2 Institut de Physique du Globe de Paris, Sorbonne Paris Cité, Université Paris Diderot, UMR 7154 CNRS, \\ 75005 Paris, France; barrier@ipgp.fr \\ 3 CASP, West Building, Madingley Rise, Madingley Road, Cambridge CB3 0UD, UK; \\ gloria.heilbronn@casp.cam.ac.uk \\ 4 College of Earth and Planetary Sciences, University of Chinese Academy of Sciences, No. 19A Yuquan Road, \\ Beijing 100049, China; jiayingying@mail.iggcas.ac.cn \\ 5 Key Laboratory of Orogenic Belts and Crustal Evolution, Ministry of Education, School of Earth and Space \\ Sciences, Peking University, Beijing 100871, China; zjguo@pku.edu.cn \\ 6 Research Station of the Russian Academy of Sciences, Bishkek 720049, Kyrgyzstan; bataleva@gdirc.ru \\ * Correspondence: marc.jolivet@univ-rennes1.fr
}

Received: 1 May 2018; Accepted: 29 August 2018; Published: 3 September 2018

check for updates

\begin{abstract}
The Late Mesozoic-Cenozoic topographic and climate evolution of Central Asia remains highly debated. The final retreat of the proto-Paratethys Sea from the western Tarim Basin is thought to correspond in time with the onset of tectonic uplift in the Pamir, Tian Shan and Altai ranges, as well as with regional aridification. The oxygen and carbon isotope compositions of the sediment deposits in the various Central Asian basins have already been used to decipher both the topographic and climatic changes that occurred in that region during the Cenozoic, generally concentrating on one sedimentary section and/or on a limited time range and either using multiple-type samples including sandstone calcitic cements, marine carbonates, fossils, or paleosols. In order to get a homogeneous dataset, minimizing variations in the isotopic composition of the material depending on its type and/or depositional environment, we selected only calcareous paleosols sampled in several continuous sections covering a wide time range from the Late Jurassic to the Pliocene. Our sampling also covers a wide area encompassing the whole Tian Shan region, which allows detecting regional variations in the $\delta^{18} \mathrm{O}$ and $\delta^{13} \mathrm{C}$ values. We show that the influence of the distance to the proto-Paratethys Sea on the paleosol $\delta^{18} \mathrm{O}$ record was not significant. Besides local factors such as the occurrence of large lakes that can have a significant effect on the isotopic composition of the calcareous paleosols, the long-term evolution of both the $\delta^{18} \mathrm{O}$ and $\delta^{13} \mathrm{C}$ values possibly reflects the hypsometry of the river drainage systems that bring water to the basins. However, as it is commonly accepted that the $\delta^{18} \mathrm{O}$ of soil carbonates is controlled by the $\delta^{18} \mathrm{O}$ of in-situ precipitation, this last conclusion remains to be further investigated.
\end{abstract}

Keywords: Central Asia; late Mesozoic-Cenozoic climate; hypsometry; calcareous paleosols 


\section{Introduction}

In Central Asia, the arid to semi-arid region extending north of the Tibet plateau is characterized by several large sedimentary basins separated by the high ranges of the Tian Shan, Altai and Pamir mountain belts (Figure 1). The present-day topography of Central Asia resulted from the reactivation, by the India-Asia collision stress field, of inherited Late Paleozoic geological structures [1-4]. It is commonly suggested that during the Upper Cretaceous and the Paleogene, the topography of Central Asia was characterized by low-relief basement areas surrounding sedimentary basins [3,5-7]. At that time, marine water from the proto-Paratethys Sea invaded and retreated from the western Tarim and Fergana basins to the south-west [8-10], while the Junggar Basin remained largely endoreic (Figure 1). The last marine regression, dated to the late Eocene, could coincide in time with the onset of deformation and relief building in the Pamir and Tian Shan ranges [10-12]. These two events are also contemporaneous with the development of a monsoon-type rainfall regime in Central Asia marking the onset of the Indian and SE Asia monsoons [13,14]. Finally, although evidence of a semi-arid climate has been identified in the Late Jurassic and Cretaceous sediment series of the Central Asian basins [4], it has been suggested that the late Eocene topographic and atmospheric changes induced enhanced aridification in Central Asia (e.g., [13,14]). However, due to the complexity of the interactions between global climate change, the tectonic uplift of the Asian ranges, including the Tibet plateau to the south, and the regression of the proto-Paratethys Sea to the west, the Late Mesozoic-Cenozoic topographic and climatic evolution of Central Asia is still strongly debated (e.g., $[4,8,10,15])$.

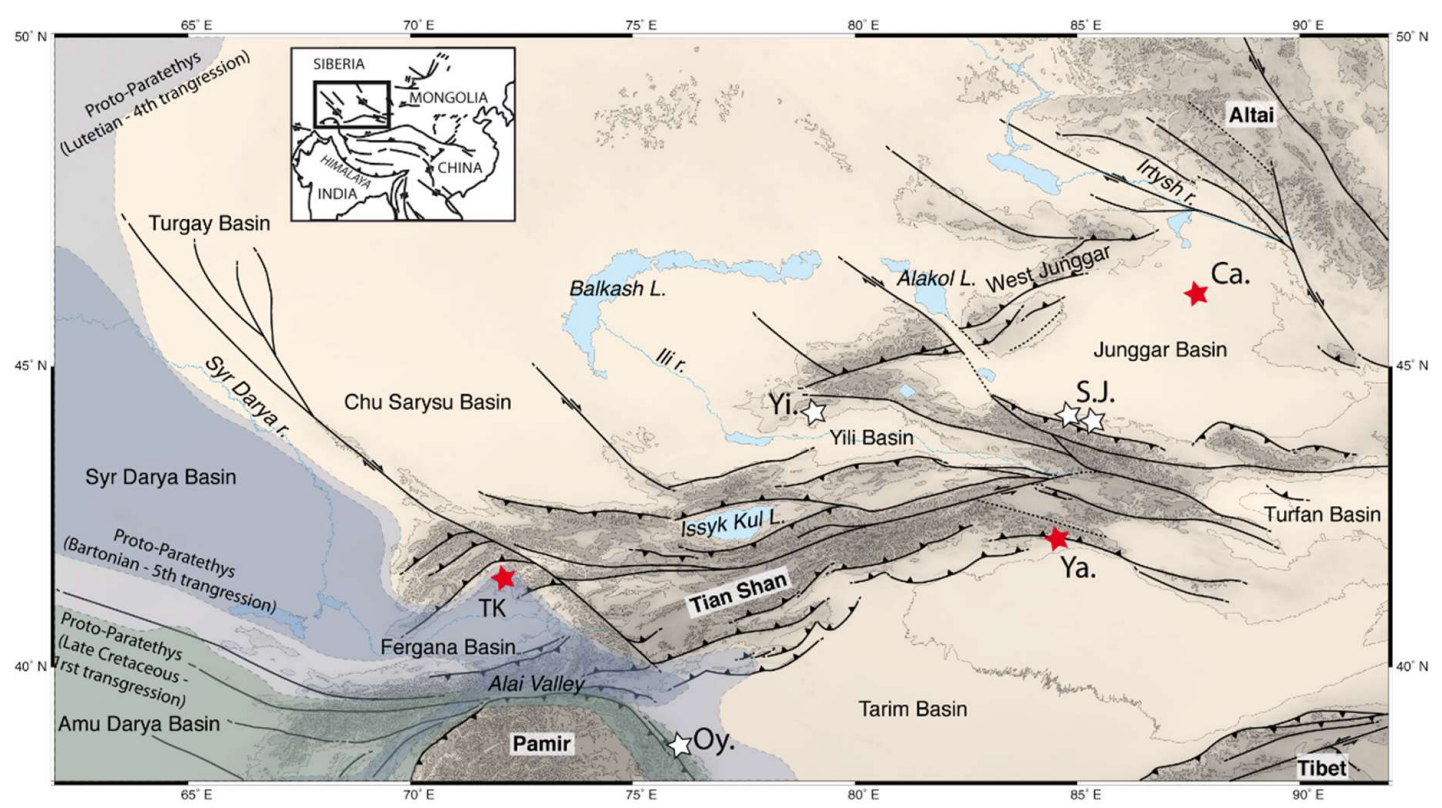

Figure 1. General topographic and structural map of the region surrounding the Tian Shan Range. The red stars indicate the location of the sections studied in this work (TK: Tash Komyr, Ca: Central Junggar Canyon, Ya: Yaha (this study and [16])); the white stars indicate the location of data obtained from the literature (S.J.: South Junggar [15,16], Oy.: Oytag [12], Yi.: Yili Basin [17]). The blue and green shaded areas represent the various incursions of the proto-Paratethys sea (modified from [10]).

The oxygen and carbon isotope signatures of sediment deposits have already been used in the Tian Shan region to try to better constrain its topographic $[12,15]$ and climatic evolution $[17,18]$. Pedogenic carbonates form in semi-arid to arid climates characterized by precipitations lower than $100 \mathrm{~cm} \cdot \mathrm{yr}^{-1}$ [19-21]. The $\delta^{18} \mathrm{O}$ of soil carbonates is controlled by the $\delta^{18} \mathrm{O}$ of soil water, itself primarily depending on the $\delta^{18} \mathrm{O}$ of meteoric water (e.g., [22]) brought either from in situ rainfall or possibly from rivers. Meteoric water $\delta^{18} \mathrm{O}$ is governed by isotopic fractionation in the atmosphere, the $\delta^{18} \mathrm{O}$ 
value decreasing with latitude and altitude following the decrease in atmospheric temperature, as well as with the distance to the marine sources (the "continental effect" [23]), although this last parameter has recently been shown to generate minor isotopic variations over large distances [24]. In addition, strong evaporation in low-precipitation regions can significantly enrich soil water in ${ }^{18} \mathrm{O}$ (increasing the $\delta^{18} \mathrm{O}$ value) compared to the local meteoric water (e.g., [22,25]), which impedes the straightforward reconstruction of paleoenvironmental conditions. Similarly, the $\delta^{13} \mathrm{C}$ value of soil carbonates being set by the isotope composition of soil gas $\mathrm{CO}_{2}$ mixed with atmospheric $\mathrm{CO}_{2}$, it is correlated to the isotopic composition of soil $\mathrm{CO}_{2}[22,26]$. However, the carbon isotope composition of soil is controlled by numerous and complex processes. It decreases with increasing latitude and altitude mostly because of the variations in soil respiration capacities [26-30]. In contrast, a decrease in microbial activity in the soil, for example through increasing aridity, can increase the $\delta^{13} \mathrm{C}$ value in the soil carbonates [31,32]. Similarly, varying plant rooting depth and amount of rain will control the depth of formation of the soil carbonates through precipitation and re-dissolution processes [33]. The $\delta^{13} \mathrm{C}$ value also depends strongly upon the proportion of C4 and C3 type plants [26,34], although C4 plants-dominated the ecosystems that arose during the late Miocene [27,35-37] and represent a fraction less than $10 \%$ of the present-day vegetation in the Tian Shan region and more generally in Central Asia [38]. Nonetheless, in some localities such as the Yili Basin (Figure 1), the density of C4 plants might be higher [39].

In this paper, we use the oxygen and carbon isotope compositions of calcareous paleosols to discuss the general Late Mesozoic to Pliocene climate evolution in the Tian Shan region, as well as the influence of the proto-Paratethys Sea and of the topographic growth of the Pamir, Tian Shan and Altai ranges, on the isotopic signal specifically registered in this type of soil.

\section{Geological Context}

\subsection{Tectonic and Topography}

The Tian Shan and Altai ranges (Figure 1) belong to the Central Asian Orogenic Belt which results from the multiple accretion of island arcs and continental blocks throughout the Paleozoic [40]. From the Early Jurassic, following several major episodes of Late Paleozoic-Early Mesozoic relief building [3,41-44], the long-term topographic evolution of the Tian Shan and Altai ranges was characterized by a progressive decrease in relief that ultimately led to the formation of a wide planation surface reaching its maximum extension during the Paleogene $[4,5,45,46]$. Nonetheless, several episodes of deformation and relief reactivation have been identified during the Late Mesozoic. Low temperature thermochronology data from NE Altai (e.g., [47]), and the Tian Shan [48], as well as sedimentological evidence (sediment petrology, facies assemblages and sediment provenances) from the Fergana, northern Tarim and Junggar basins [11,49-52], indicate Late Jurassic -Early Cretaceous exhumation associated with relief building in both ranges. Similar data, as well as the occurrence of angular non-conformities within the major basins, also document a Late Cretaceous -early Paleogene exhumation event affecting most of the Central Asian ranges [42-44,53,54]. However, the Mesozoic planation surface largely preserved within the present-day topography of the Tian Shan and Altai ranges suggests that, in spite of these episodes of tectonic activity during the Late Jurassic and Cretaceous periods, the associated topographies were limited in size and probably restricted along the main tectonic structures affecting the ranges [3,7]. During the Cenomanian, a transgression phase of the Paratethys Sea reached the western Tarim Basin through the paleo-Alai Valley, between the Pamir and Tian Shan ranges [8-10]. This first transgression initiated a series of five transgression-regression cycles that ended in the late Eocene and flooded both the Fergana and western Tarim basins [10] (Figure 1). Although this topic remains highly debated, the final regression of the Paratethys Sea slightly precedes the commonly admitted late Oligocene-early Miocene increase in uplift rate of the Pamir salient along the western margin of the Tarim Basin (Figure 1) [12,55,56]. Similarly, incipient compressive deformation driven by the India-Asia collision occurred along the southern front of the Tian Shan during the late Eocene-Oligocene [11,57,58], but it remained limited until the Miocene [42,59]. Finally, 
Oligocene-Miocene deformation also affected the Altai Range, although its main Cenozoic relief building occurred since the late Miocene $[3,6,29,60,61]$.

\subsection{Climate}

In the Fergana, Tarim and Junggar basins, the Late Jurassic period was marked by a progressive aridification $[49,50,62]$, which probably reached its climax at the Upper Jurassic-Lower Cretaceous transition with the development of large aeolian dune fields in the Junggar Basin [52]. Although a strong latitudinal climate gradient existed during the Cretaceous in Asia, the Tian Shan-western Altai region remained affected by warm semi-arid, seasonal conditions throughout the Lower Cretaceous $[11,49,50,63,64]$. Nonetheless, lake systems developed in the Junggar Basin, potentially related to the formation of a rain shadow linked to the renewed uplift of the Tian Shan and possibly Altai ranges [49]. Afterward, while the Cenomanian-Turonian period seems to correspond to a climatic optimum in NE Asia [65], Central Asia remained under semi-arid conditions throughout the Upper Cretaceous as indicated by the widespread development of calcareous paleosols in the area $[16,49,64,66,67]$. Finally, the evolution of the Cenozoic climate in Central Asia is still highly controversial. The monsoons possibly initiated as early as Eocene times, implying a seasonal, semi-arid climate in the Tian Shan region $[13,14,18,68,69]$. It has also been suggested that the final retreat of the proto-Paratethys Sea from the Tarim Basin further increased the aridity in the Tarim region [8]. The proposed age for the Cenozoic onset of desertification in the Tarim Basin varies from $26.7 \mathrm{Ma}$ [70] to $3.4 \mathrm{Ma}$ [71] and possibly younger, but much published sedimentological and geochemical data also support an Oligocene-early Miocene aridity increase in Central Asia (e.g., [17,55,72-74]). However, the driving mechanism for this aridification is widely debated including an enhanced East Asian winter monsoon [72] or uplift of the Tian Shan and Tibet ranges [70]. Superimposed on this aridity increase, the Cenozoic climate was also marked by a series of short-lived wetter periods [75]. The climate of the Tian Shan region is now controlled by moisture carried by the mid-latitude westerlies that generate orographic precipitation when interacting with the Tian Shan and Altai topographies [29,76-78]. The mean position of the westerly jet was probably further to the north during the late Miocene [79], and [29] suggesting that by late Miocene time, the Altai and Tian Shan ranges were high enough to prevent moisture from reaching the Tarim Basin and the Gobi desert.

\section{Oxygen and Carbon Isotope Analysis of Calcareous Paleosols}

\subsection{Sampling Strategy}

Whereas some of the isotopic studies of Central Asia used very specific samples representative of one type of environment (for example, Reference [18] used oyster shells, addressing marine environments), most of them used a wide range of material, from lacustrine to marine carbonates, carbonate cements in alluvial sandstones, calcareous paleosols, or fossils. This variety of sample types, although providing high-resolution sampling, sometimes makes for a large dispersion in the results due to variations in chemical processes during the formation of the carbonates (such as the amount of evaporation) [22,80-82], or to the individual sensitivity of different types of samples to diagenetic processes [83]. In order to minimize this effect, we focused our sampling on caliche and calcrete, and we complemented the newly acquired data with already published results on similar materials.

To increase our knowledge on the Meso-Cenozoic paleoenvironmental evolution of Central Asia, we collected calcareous paleosol samples over a vast area (Figure 1). Furthermore, to document the long-term evolution of the oxygen and carbon isotope signal we collected samples over a wide stratigraphic age range from the Late Jurassic to the middle Miocene. These data are complemented up to the Pliocene by previously published work.

All samples were micro-drilled for subsamples to avoid as much as possible contamination by detrital minerals. Most samples correspond to bulk cement impregnation. In some locations, small calcite veins contained inside the samples were analyzed to detect potential diagenetic inprints due to 
late fluid circulation. Some samples were doubled to assess possible variations between individual nodules in the same paleosol that would reflect either primary variation during carbonate precipitation, differential diagenetic effects or contamination by detrital grains from the sediment.

\subsection{Field Sampling and Samples}

Sampling was performed on three sections (Tash Komyr, Yaha and central Junggar Canyon) that are described below in detail. These data were complemented using already published calcareous paleosols isotopic composition data (see discussion below).

The Tash Komyr section in the Fergana Basin exposes a continuous sediment record from the Middle Jurassic to the Paleogene (Figures 2 and 3A) and is described in detail in [64]. The Upper Jurassic Balabansay Formation [84] corresponds to a distal alluvial plain environment. The sediments contain calcareous nodules sometimes associated with root traces. The base of the Cretaceous series is marked by the Oxfordian to Valanginian thick alluvial fan sediments of the Hodzhiabad Formation [85], intruded by a magmatic sill dated at ca. $143 \mathrm{Ma}$ using U-Pb on apatite [64]. The Cretaceous deposits are entirely continental terrigenous, evolving from distal alluvial plain and shallow lake environments in the Lower Cretaceous to a proximal alluvial plain in the Upper Cretaceous and up to the Ypresian. Several Hadrosauridae dinosaur eggs have been discovered in the Upper Cretaceous series, dating them to the Coniacian to Maastrichtian and confirming the position of the Cretaceous-Paleocene boundary indicated on the geological map $[64,86]$. The Suzak Formation corresponding to Ypresian and Bartonian series then displays marine carbonates corresponding to the third incursion of the proto-Paratethys Sea in the eastern Fergana Basin, inter-layered with continental sandstones (Figures 1, 2 and 3A) [10,87]. Calcareous paleosols occur within the whole Cretaceous and Paleogene continental series and are present in the continental sandstone layers inter-stratified between the marine beds of the Suzak Formation. In the Lower Cretaceous, they consist of decimeter to meter thick caliches made of amalgamated root casts, separated by several meter-thick layers of sandstone (Figure 3B,D). The frequency and thickness of the caliche layers increases the up-section and the Paleocene series are formed of several meter thick caliches interbedded with coarse sandstone and gravel layers, themselves impregnated by carbonates (Figure 3C,E). Samples were collected mainly from the Cretaceous and Paleogene caliches and correspond to cement impregnations. However, sample TK-15 from the Balabansay Formation corresponds to a calcareous nodule, while sample TK16 was obtained from calcite-coated pebbles in the Hodzhiabad Formation conglomerates. Samples TK17A, TK25, TK31B and TK34 correspond to calcite veins within the caliche (Table 1 and Figure 2).

Table 1. Oxygen and carbon isotope compositions of the samples analyzed in this study. Samples marked with a star $\left(^{*}\right)$ are from [16]. $\delta^{18} \mathrm{O}$ values are relative to VSMOW and $\delta^{13} \mathrm{C}$ values to VPDB.

\begin{tabular}{ccccc}
\hline Sample & Age & Type & $\boldsymbol{\delta}^{\mathbf{1 8}} \mathbf{O}\left(\boldsymbol{\%}_{0}\right)$ & $\boldsymbol{\delta}^{\mathbf{1 3}} \mathbf{C}\left(\mathbf{\%}_{\mathbf{0}}\right)$ \\
\hline TK15 & Tash Komyr Section (Fergana Basin) & & \\
TK16 & Barthonian-early Oxfordian & Nodule & 24.4 & -13.2 \\
TK17A & Oxfordian-Valanginian & Calcite coating on pebble & 22.3 & -0.4 \\
TK17B & Cretaceous & Calcite vein in caliche & 21.6 & -4.4 \\
TK18 & Cretaceous & Caliche & 21.8 & -4.2 \\
TK19 & Cretaceous & Caliche & 21.8 & -6.0 \\
TK20 & Cretaceous & Caliche & 22.4 & -6.8 \\
TK22 & Cretaceous & Caliche & 22.8 & -6.8 \\
TK24 & Coniacian-Maastrichtian & Caliche & 22.5 & -7.2 \\
TK25 & Coniacian-Manstrichtian & Caliche & 22.6 & -6.1 \\
TK26 & Coniacian-Maastrichtian & Calcite vein in caliche & 23.2 & -7.2 \\
TK27 & Cretaceous-Paleogene & Caliche & 23.9 & -6.9 \\
TK28 & Paleocene & Caliche & 24.4 & -5.0 \\
TK29 & Paleocene & Caliche & 23 & -5.9 \\
TK31A & Paleocene & Caliche & 20.8 & -6.4 \\
TK31B & Paleocene & Caliche & 27.2 & -5.2 \\
\hline
\end{tabular}


Table 1. Cont.

\begin{tabular}{|c|c|c|c|c|}
\hline Sample & Age & Type & $\delta^{18} \mathrm{O}(\%)$ & $\delta^{13} \mathrm{C}(\%)$ \\
\hline \multicolumn{5}{|c|}{ Tash Komyr Section (Fergana Basin) } \\
\hline TK33 & Paleocene & Caliche & 21.8 & -6.5 \\
\hline TK34 & Paleocene & Calcite vein in caliche & 20.3 & -5.7 \\
\hline TK38 & Ypresian-Bartonian & Caliche & 21.8 & -1.0 \\
\hline TK39 & Ypresian-Bartonian & Caliche & 28 & 0.1 \\
\hline TK40 & Ypresian-Bartonian & Caliche & 30 & 0.4 \\
\hline \multicolumn{5}{|c|}{ Canyon section (Junggar Basin) } \\
\hline $\mathrm{J} 3$ & Late Cretaceous & Nodule & 26.5 & -6.0 \\
\hline $\mathrm{J} 5$ & Late Cretaceous & Nodule & 26.0 & -7.2 \\
\hline J7 & Late Cretaceous & Nodule & 23.5 & -6.3 \\
\hline $\mathrm{J} 13$ & Paleogene & Caliche/Calcrete & 18.6 & -7.3 \\
\hline $\mathrm{J} 15 \mathrm{~A}$ & Oligocene & Caliche/Calcrete & 19.2 & -6.8 \\
\hline $\mathrm{J} 15 \mathrm{~B}$ & Oligocene & Calcite vein in caliche & 18.8 & -7.1 \\
\hline $\mathrm{J} 17$ & Oligocene & Caliche/Calcrete & 18.2 & -7.5 \\
\hline $\mathrm{J} 20$ & Oligocene & Caliche/Calcrete & 18.5 & -7.3 \\
\hline $\mathrm{J} 22 \mathrm{~A}$ & Oligocene & Caliche & 18.2 & -7.9 \\
\hline $\mathrm{J} 22 \mathrm{~B}$ & Oligocene & Caliche & 18.3 & -7.4 \\
\hline $\mathrm{J} 25$ & Late Oligocene-Miocene & Caliche/Calcrete & 19.1 & -11.7 \\
\hline $\mathrm{J} 27$ & Miocene & Calcite vein in caliche & 18.4 & -9.3 \\
\hline $\mathrm{J} 28 \mathrm{~A}$ & Miocene & Caliche & 18.6 & -9.4 \\
\hline $\mathrm{J} 28 \mathrm{~B}$ & Miocene & Calcite vein in caliche & 18.5 & -9.3 \\
\hline $\mathrm{J} 29$ & Miocene & Caliche/Calcrete & 18.6 & -8.3 \\
\hline $\mathrm{J} 29$ & Miocene & Caliche/Calcrete & 18.5 & -8.3 \\
\hline $\mathrm{J} 30$ & Miocene & Caliche/Calcrete & 18.6 & -8.5 \\
\hline \multicolumn{5}{|c|}{ Yaha section (North Tarim Basin) } \\
\hline YA 12 SED $18 *$ & Cretaceous-Priabonian & Caliche & 22.7 & -4.8 \\
\hline YA 12 SED $17^{*}$ & Cretaceous-Priabonian & Caliche & 22.7 & -5.0 \\
\hline YA 12 SED $16^{*}$ & Cretaceous-Priabonian & Caliche & 21.7 & -3.9 \\
\hline YA 12 SED 13 * & Cretaceous-Priabonian & Caliche & 21.6 & -4.1 \\
\hline Y37A & Maastrichtian & Caliche & 22.8 & -3.0 \\
\hline Y37B & Maastrichtian & Caliche & 21.0 & -2.1 \\
\hline Y38A & Maastrichtian & Caliche & 22.0 & -3.8 \\
\hline Y38B & Maastrichtian & Caliche & 22.1 & -3.5 \\
\hline Y38C & Maastrichtian & Caliche & 20.9 & -5.0 \\
\hline Y39 & Maastrichtian & Caliche & 22.4 & -4.0 \\
\hline Y40A & Maastrichtian & Caliche & 22.3 & -3.6 \\
\hline Y40B & Maastrichtian & Caliche & 22.0 & -3.6 \\
\hline Y41 & Maastrichtian & Caliche & 21.2 & -3.7 \\
\hline YA 12 CHIM 1 * & Lower Cretaceous & Nodule & 24.6 & -3.0 \\
\hline
\end{tabular}

The series exposed in the Canyon section in the central Junggar Basin (Figures 2 and 4A) have been described in detail by $[73,88-90]$, which display the Upper Cretaceous series based on the occurrence of Pseudohyria bivalves associated with reptilian bone fragments [91]. These fine- to medium-grained sandstone deposits likely correspond to distal alluvial plain or deltaic deposits. The section is marked by an unconformity separating the Upper Cretaceous deposits from the Paleogene to middle Miocene series again representing fluvio-lacustrine and aeolian depositional environments [73,88-90]. The top of the section is marked by an erosion surface overlain by a Quaternary terrace system. Calcareous paleosols are scarce in the Cretaceous deposits, represented by layers of centimeter to decimeter thick calcareous nodules (Figure 4B,C). In the Cenozoic series however, the lowest paleosols (Oligocene) are formed by a mixture of calcrete and caliche beds, with the occurrence of individual root casts that are not amalgamated as in the Tash Komyr section (Figure 4D,F). The late Oligocene-Miocene paleosols are composed of large amalgamated nodules (Figure 4E,G). All samples correspond to cement impregnation, except samples J15B, J27 and J28B, which are calcite veins contained inside the paleosols. Finally, samples J22 and J29 were doubled to look for possible variations between individual nodules in the same paleosol. 

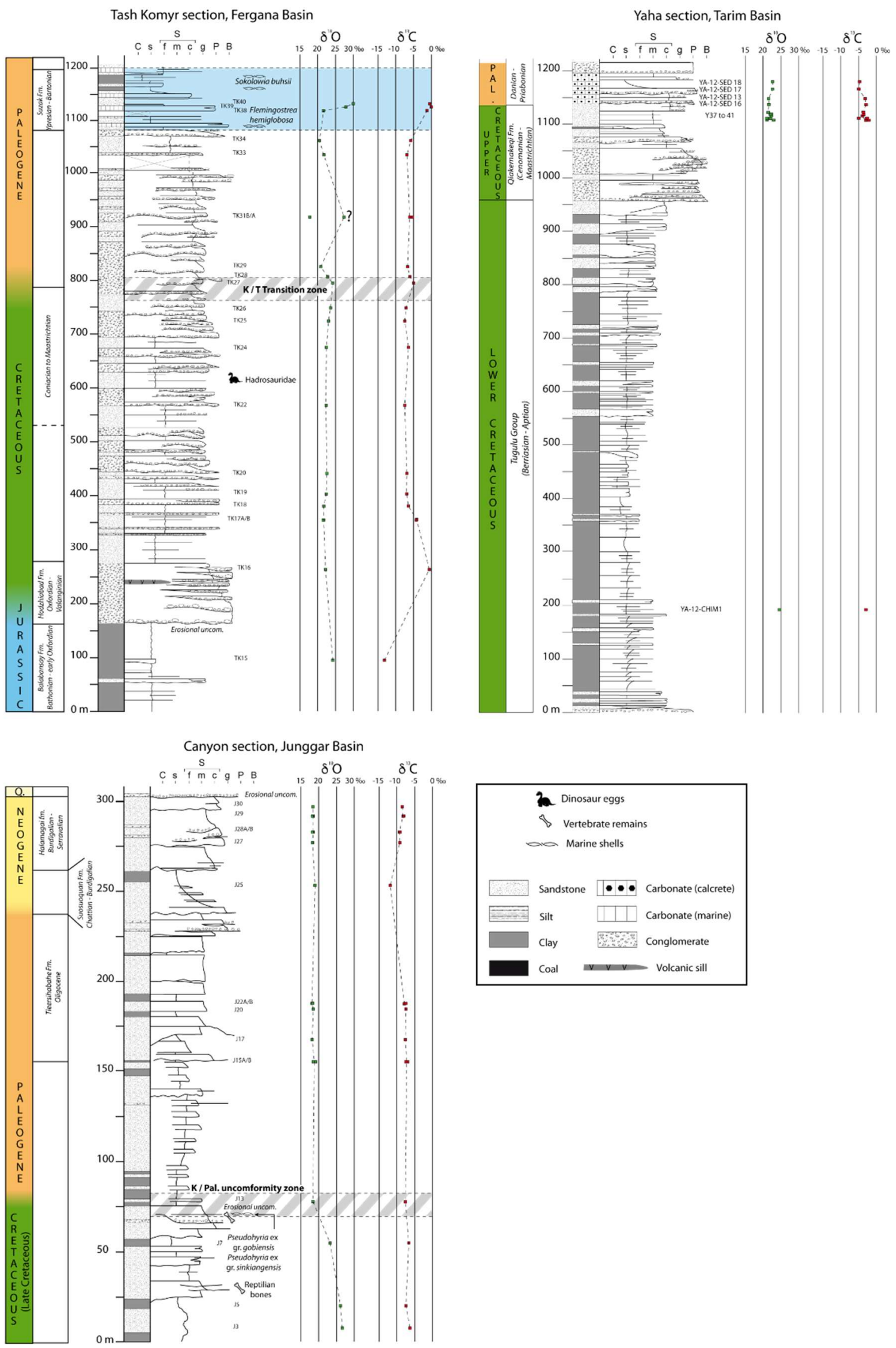

Figure 2. Stratigraphic sections from the three main locations studied in this work, with $\delta^{18} \mathrm{O}$ (in reference to VSMOW) and $\delta^{13} \mathrm{C}$ (in reference to VPDB) values. In the Tash Komyr section, the blue shading corresponds to series including marine sediments of the proto-Paratethys sea (modified from [63]). See Table 1 for details on isotopic compositions. 

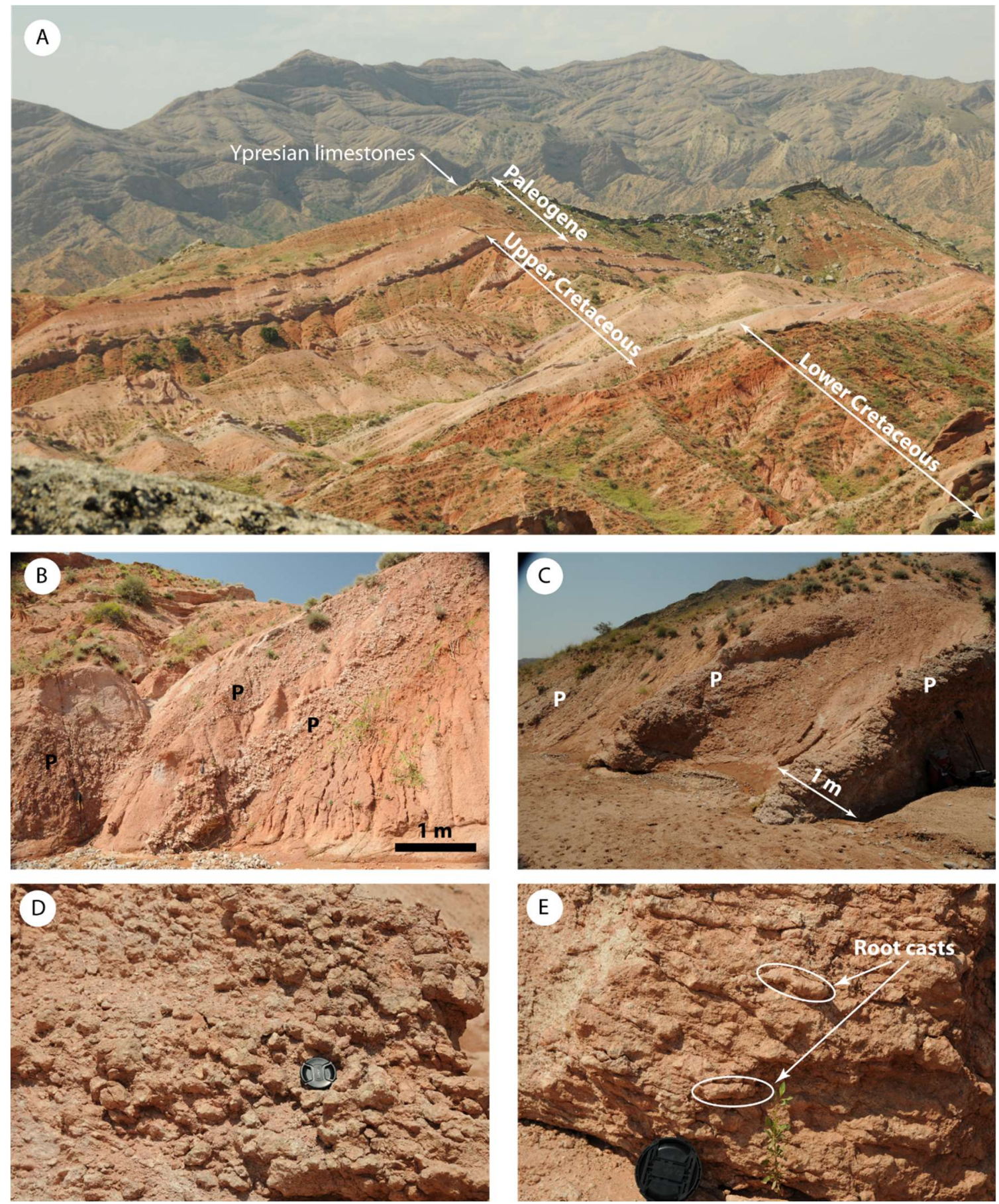

Figure 3. (A) General view of the Tash Komyr section (the distance is about $1.3 \mathrm{~km}$ from the base of the exposed Cretaceous series to the Ypresian limestones). (B) Early Cretaceous caliche layers (P). (C) Paleogene caliche layers (P). (D,E) Close view of the amalgamated root casts in the Early Cretaceous and Paleogene caliches. 

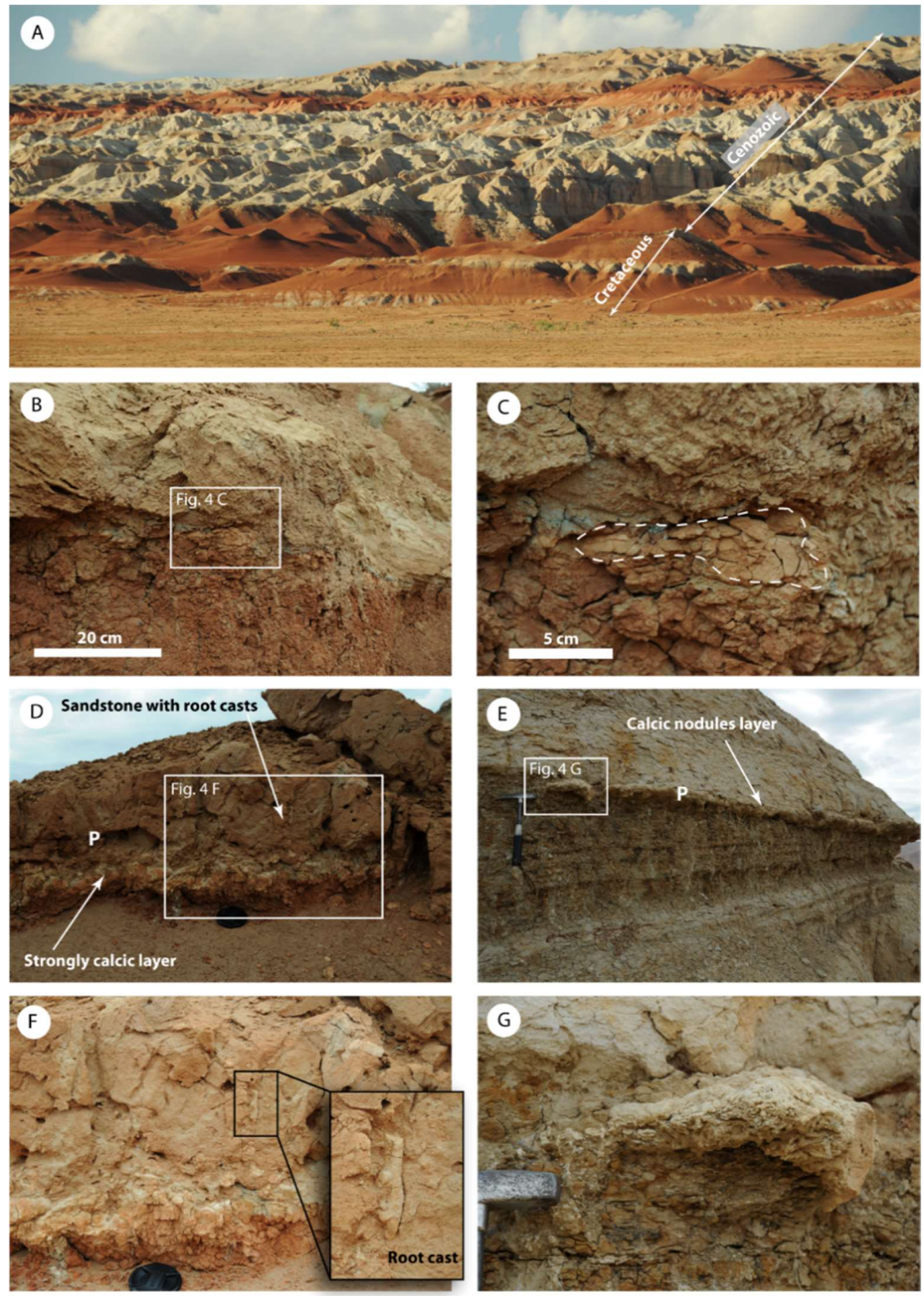

Figure 4. (A) General view of the Central Junggar Canyon section (the distance between the bottom and the top of the section is about $1 \mathrm{~km})$. (B,C) Calcareous nodules forming the Late Cretaceous paleosols. (D) Quaternary paleosol layer including individual root casts (detail on F). (E) Quaternary paleosol formed by near coalescent calcareous nodules (detail on $\mathbf{G}$ ).

The Yaha section in the northern Tarim Basin (southern Tian Shan foothills) displays Middle Jurassic to Quaternary series [49,92] (Figures 2 and 5A). As in Tash Komyr, the base of the Cretaceous is marked by a thick alluvial fan, the Kalaza Formation [93], developed in arid conditions [52] (Figure 2). The Lower Cretaceous sediments mostly correspond to fine grained, red distal alluvial plain deposits. Mud cracks and root traces again suggest a semi-arid climate [49], although only few calcareous nodules were found (sample YA 12 CHIM 1 of [16]) (Figure 5A). The Upper Cretaceous series are coarser and correspond to a proximal alluvial plain. They contain decimeters-thick calcareous paleosols (caliches) increasing in frequency towards the top (samples Y37 to Y41) (Figures 2 and 5B). Finally, several meters-thick massive layers of calcrete impregnating conglomerates or sandstones mark the Cretaceous-Paleogene transition (samples YA 12 SED 13 to YA 12 SED 18 of [16]) [91] (Figure 5C-E). The base of this calcrete has been dated to ca. $66 \mathrm{Ma}$ [94] and the top to ca. $35 \mathrm{Ma}$ [95] using 
magnetostratigraphy. As in the Canyon section, several samples were duplicated to track possible diagenetic effects, especially in the caliche layers below the massif calcrete beds (Table 1).
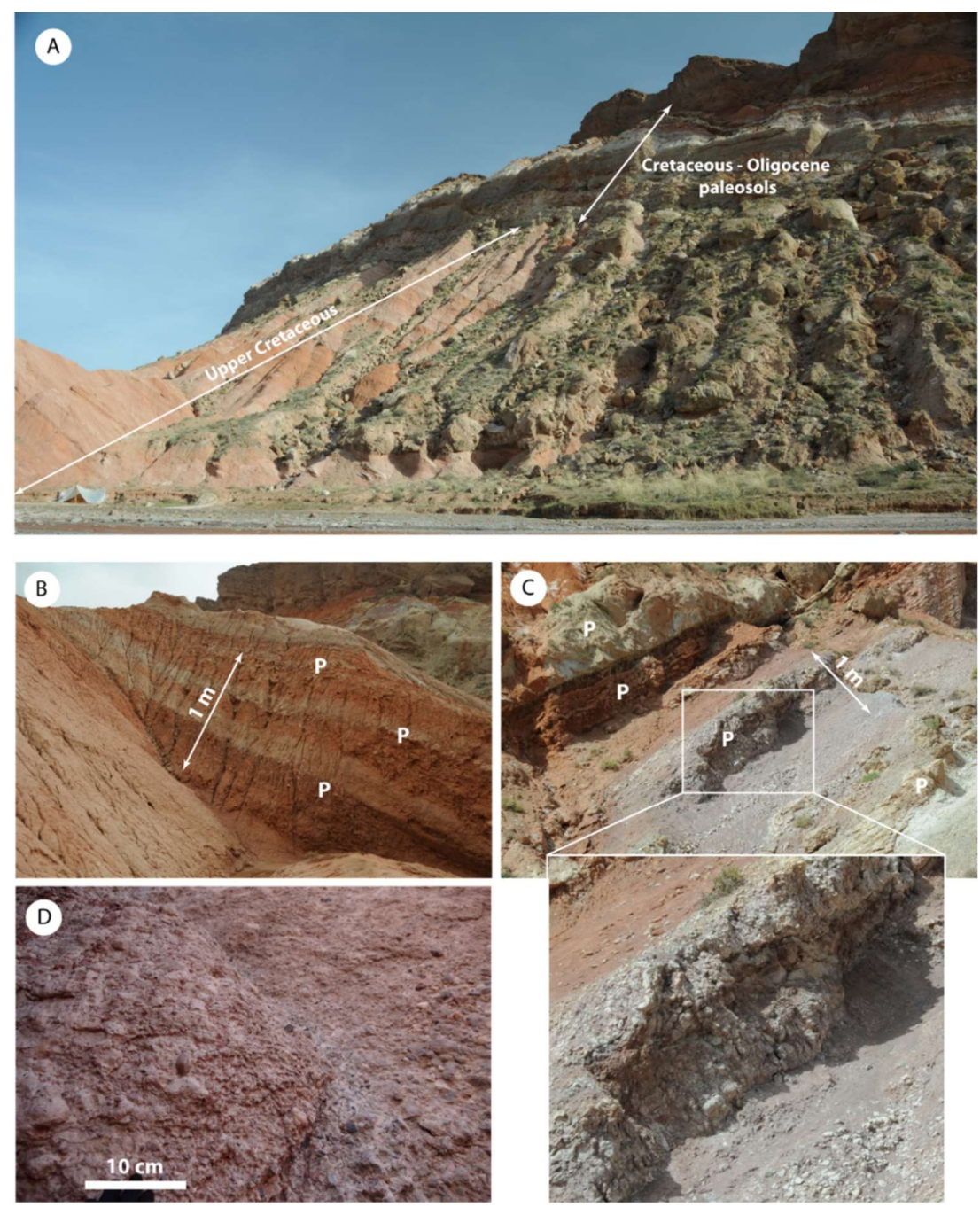

Figure 5. (A) General view of the Late Cretaceous to Paleogene series of the Yaha section. (B) Late Cretaceous calcareous paleosols. (C) Large scale view and details of the Late Cretaceous-Paleogene multilayered caliches. (D) Detailed view of a massive Late Cretaceous-Paleogene calcrete layer developed within a conglomerate.

\subsection{Analytical Techniques}

The stable isotope analyses were conducted at Géosciences Rennes, University Rennes 1 . For each sample, about $12 \mathrm{mg}$ of calcite powder were reacted with anhydrous $\mathrm{H}_{3} \mathrm{PO}_{4}$ for several hours at $50{ }^{\circ} \mathrm{C}$. The produced $\mathrm{CO}_{2}$ was analyzed on a VG Optima triple collector mass spectrometer. The accuracy of the results was controlled through routine analysis of in-house standards (Prolabo Rennes) and NBS 19 international standards. The measurement precision was estimated at $\pm 0.15 \%$ for oxygen (VSMOW) and $\pm 0.10 \%$ for carbon (VPDB).

\subsection{Results}

\subsubsection{Tash Komyr Section}

The isotopic data are reported in Table 1 and Figures 2 and 6. In the Tash Komyr section (Fergana Basin), the Late Jurassic sample TK15 showed a $\delta^{18} \mathrm{O}$ value of $24.4 \%$ and a $\delta^{13} \mathrm{C}$ of $-13.2 \%$, 
the latest being anomalously much lower than the other samples in the section. The $\delta^{18} \mathrm{O}$ values of the Cretaceous samples were between $21.6 \%$ and $23.9 \%$, consistent but slightly lower than the Jurassic value, even if slightly increasing in the up-section. The $\delta^{13} \mathrm{C}$ values of these Cretaceous samples were homogeneous, ranging between $-6.0 \%$ and $-7.2 \%$, except for the lowest samples TK16 and TK17A/B, which provide higher values of $-0.4 \%$ and -4.4 to $4.2 \%$, respectively. One can also notice that sample TK16 $\left(\delta^{13} \mathrm{C}=-0.4 \%\right)$ corresponded to the calcite coating around pebbles at the top of the Late Jurassic-Cretaceous alluvial fan deposits. Samples TK27 to TK29 at the Cretaceous-Paleogene transition then showed a noticeable decrease in both $\delta^{18} \mathrm{O}$ and $\delta^{13} \mathrm{C}$ values from $24.4 \%$ to $20.8 \%$ and $-5.0 \%$ to $-6.4 \%$, respectively. Following this decrease, both isotopic ratios remained stable, around 20 to $22 \%$ for $\delta^{18} \mathrm{O}$ and -5 to $-6.5 \%$ for $\delta^{13} \mathrm{C}$. Sample TK31 Was outside the general $\delta^{18} \mathrm{O}$ trend, suggesting a late perturbation of the isotopic system, although this event was not registered in the carbon isotopic signal. Finally, the three last samples, corresponding to the Ypresian-Bartonian period of marine incursions, showed a clear marine influence with $\delta^{18} \mathrm{O}$ values increasing up to $30 \%$ and the $\delta^{13} \mathrm{C}$ values reaching $0 \%$. These last four samples will not be considered in the following discussion.
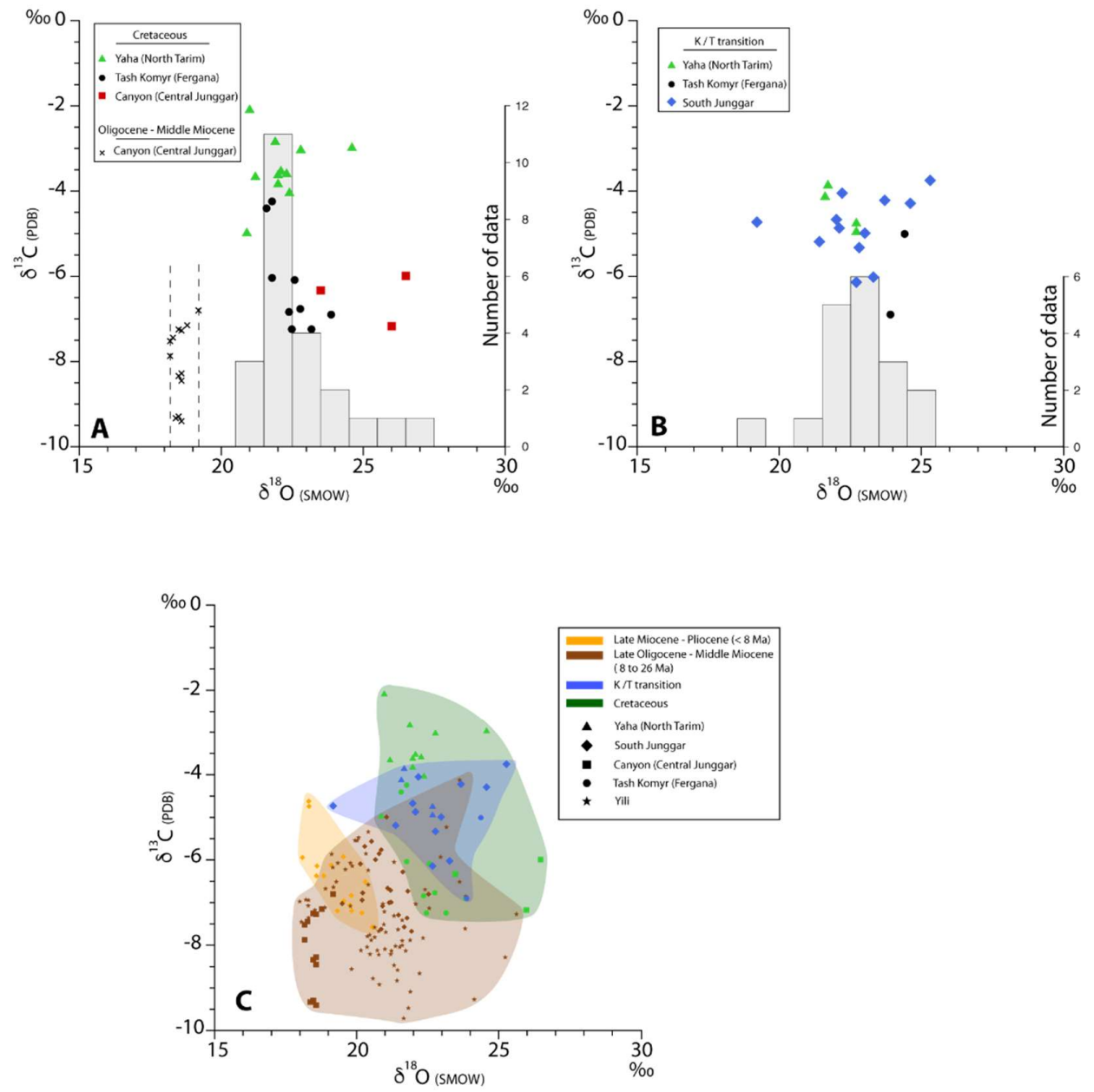

Figure 6. (A) Oxygen versus carbon isotope composition of the Cretaceous and Quaternary samples from the three studied sections. The histogram represents the frequency distribution of $\delta^{18} \mathrm{O}$ values for the Cretaceous samples. (B) Oxygen versus carbon isotope composition of the Cretaceous-Paleogene transition samples from the Yaha and Tash Komyr sections (this study), as well as from the South Junggar [16]. The histogram represents the frequency distribution of the $\delta^{18} \mathrm{O}$ values. (C) Oxygen versus carbon isotope composition of calcareous paleosols (caliche, calcrete and carbonated nodules) from this study and from the literature [15-17]. The color-shaded areas correspond to sample age groups. 


\subsubsection{Yaha Section}

In the Yaha section (Tarim Basin), the Late Cretaceous (Maastrichtian) and Late Cretaceous-Eocene samples have similar $\delta^{18} \mathrm{O}$ values ranging between $20.9 \%$ and $22.7 \%$. The corresponding $\delta^{13} \mathrm{C}$ values vary from $-2.1 \%$ to $-5.0 \%$, being higher than the values observed in the two other sections. The Early Cretaceous sample (YA 12 CHIM 1 of [16]) [63] collected in the same section, had a higher $\delta^{18} \mathrm{O}$ value of $24.6 \%$ and a similar $\delta^{13} \mathrm{C}$ value of $-3.0 \%$.

\subsubsection{Canyon Section}

In the Canyon section (central Junggar Basin), the $\delta^{18} \mathrm{O}$ values of the Late Cretaceous samples decreased slightly from $26.5 \%$ to $23.5 \%$ (mean value of $25.3 \%$ ), whereas the $\delta^{13} \mathrm{C}$ values were nearly stable between $-7.2 \%$ and $-6.0 \%$ (mean value of $6.5 \%$ ). The $\delta^{13} \mathrm{C}$ values of the Oligocene-middle Miocene samples range from $-11.7 \%$ to $-6.8 \%$ (mean value of $22.5 \%$ ), lower than those of the Late Cretaceous samples. The $\delta^{18} \mathrm{O}$ values of these Cenozoic samples are even more distinguishable, being significantly lower and confined in a narrow range from $18.2 \%$ to $19.2 \%$ (mean value of $18.6 \%$ ).

In a general manner, each section displays very constant $\delta^{18} \mathrm{O}$ values except for key periods, such as the K/T transition in Tash Komyr, where the variation is $3.6 \%$, nearly twice the variability observed in the closely sampled points of the Yaha section. We are thus confident that the K/T variation in Tash Komyr is a real signal and not only "natural variability". This is also confirmed by the fact that when doubled in the same layer, paleosol samples provide very consistent values (variability of about $0.2 \%$ ) excluding sample-to-sample variations.

\section{Discussion}

\subsection{Semi-Arid to Arid Climate Conditions Prevailing since Upper Jurassic}

The occurrence of calcareous nodules and preserved root traces in the Upper Jurassic Balabansay Formation (Tash Komyr section) indicates that semi-arid climate conditions already existed in the eastern Fergana Basin by that time [63]. Evidence of aridity during the Late Jurassic-Early Cretaceous transition has also been reported in the Tarim and Junggar basins (e.g., [16,49,50,52]), indicating that these conditions prevailed throughout most of the Tian Shan region.

Similarly to the Late Jurassic periods, Late Cretaceous calcareous paleosols are widespread in Central Asia, occurring in the Bayan Shire and Iren Dabasu formations in southern Mongolia and northern China [66,67], in the Donggou Formation in the Junggar Basin or in the Qiakemakeqi Formation in the northern Tarim Basin (this study, [16,49]). In addition, the continuous appearance of caliche layers in the Cretaceous-Paleogene series of the Tash Komyr section clearly indicates that the semi-arid conditions established during the Late Jurassic persisted through the Late Mesozoic-Early Cenozoic. No evidence of wetter periods is preserved within the section although short periods of decreased aridity cannot be excluded, especially during the Lower Cretaceous where the calcareous paleosols are less abundant (Figure 3A).

Within the Late Cretaceous and Paleogene sediments, the general upward increase in frequency and thickness of the paleosols in most sections is possibly related to the near absence of tectonic activity during that period and to the correlative flattening of the topography of the Tian Shan Range. This protracted erosion phase reached its climax with the development of a wide peneplain during the Paleogene $[5,64]$. Indeed, a lower sedimentation rate in the basins, associated with the absence of significant tectonic subsidence would have favored the development of thick caliche layers. In the Junggar Basin, however, the Cretaceous paleosols are poorly developed, only represented by scattered nodules, which suggests a less favorable depositional or climatic environment (Figure 4B,C). Finally, in the northern Tarim, south Junggar and Turfan basins (Figure 1), the Cretaceous-Paleogene transition is marked by one or several thick calcrete layers, forming a condensed series spanning from ca. $66 \mathrm{Ma}$ to ca. $35 \mathrm{Ma}$ in the northern Tarim Basin [16,91,92,94,95]. The transgression and regression of the proto-Paratethys Sea in the Fergana, Tadjik and Tarim basins during the Late Mesozoic and Paleogene 
does thus not seem to have had a noticeable effect on the persistence of the semi-arid climate in the area, as also suggested by the calcareous paleosols developing immediately prior, after and in between the marine beds in Tash Komyr.

\subsection{Absence of Influence of the Distance to the Sea on the Isotopic Composition of Calcareous Paleosols}

Except for the Late Cretaceous samples collected in the central Junggar canyon, which display $\delta^{18} \mathrm{O}$ values of up to $26.5 \%$, all the Cretaceous and Cretaceous-Paleogene transition samples analyzed in the various sections have $\delta^{18} \mathrm{O}$ values comprised in the narrow range 21-25\%o (Figure 6A,B and Table 1; samples TK31A and B excluded). A single calcareous paleosol with a $\delta^{18} \mathrm{O}$ value of $22.4 \%$ obtained by [12] from the Coniacian series of the NE Pamir (Oytag section, Figure 1) also falls into that range. By Late Cretaceous-Paleocene times, the distances separating the various sampling sites from the proto-Paratethys Sea to the west were tens of kilometers for the Tash Komyr section, to hundreds of kilometers for the Yaha and central Junggar sections (Figure 1).

In detail, the Tash Komyr section displays a noticeable decrease in the $\delta^{18} \mathrm{O}$ values, and to a more limited amount in the $\delta^{13} \mathrm{C}$ values, around the Cretaceous-Paleogene transition zone (Figure 2 and Table 1). Although the data is limited, a similar decrease in the $\delta^{18} \mathrm{O}$ values seems to have occurred in the Late Cretaceous samples of the central Junggar Canyon section (samples J3, J5 and J7) (Figure 2 and Table 1). In contrast, the data obtained from the Yaha section do not register this decreasing trend, possibly due to the large time interval covered by the massive calcrete layers (about 31 Ma within a few tens of meters) and the limited sampling frequency. A decrease in $\delta^{18} \mathrm{O}$ controlled by the distance to marine water as a moisture source (increasing the distance to the sea would increase the continental effect [23]) would have implied a westward regression of the proto-Paratethys Sea. This is not documented and does not fit with the progressive eastward transgression of the proto-Paratethys Sea from the Late Cretaceous to the Paleocene-early Eocene (first to fourth transgressions, Figure 1) [8-10] Two of the three Upper Cretaceous samples from the central Junggar Basin also have a significantly higher $\delta^{18} \mathrm{O}$ value of $26-26.5 \%$ (Figure $6 \mathrm{~A}$ ) that could be related to a higher evaporation of soil water inside this strongly continental basin compared to the foothills of the Tian Shan (e.g., [22,23]).

All these observations suggest that, within the very long-term semi-arid context of the Tian Shan region, implying limited precipitation and strong soil water evaporation, the distance to the sea has no measurable effect on the $\delta^{18} \mathrm{O}$ values registered in the calcareous paleosols [96]. Only when the proto-Paratethys Sea reached the sampling area to intermittently flood it during the Ypresian to Bartonian (samples TK39 and TK40), did the $\delta^{18} \mathrm{O}$ values of precipitation increase enough to significantly increase the $\delta^{18} \mathrm{O}$ values of soil carbonates. This observation is consistent with the conclusion in [24] that the length scale controlling variations in the $\delta^{18} \mathrm{O}$ of precipitation in the mid-latitudes is probably in the order of $1000 \mathrm{~km}$.

\subsection{Evidence of Local Hydrologic Control on the Isotopic Composition of Calcareous Paleosols.}

In the central Junggar Basin (Canyon section), the $\delta^{18} \mathrm{O}$ values of the late Oligocene to middle Miocene calcareous paleosols are around 18-19\%, much lower than the local Late Cretaceous values (24-26.5\%) or more generally than all the data obtained for the Cretaceous and Cretaceous-Paleogene transition (21-25\%) (Figures 2 and 6A,B). Figure 6C shows all the data from this study plotted together with data obtained from the same types of paleosols at the Cretaceous-Paleogene transition [16], from the late Oligocene-early Miocene of the Yili Basin in Kazakhstan [17], and from calcareous pisolites in the Miocene to early Pliocene series of the northern Tian Shan foothills [15] (see location of sections on Figure 1). The late Oligocene-middle Miocene $\delta^{18} \mathrm{O}$ and $\delta^{13} \mathrm{C}$ data are largely spread between $25-18 \%$ and $-4--9.5 \%$, respectively. Nonetheless, the $\delta^{18} \mathrm{O}$ values registered in the Canyon section are tightly constrained between $18-19 \%$ and are very low compared to the whole dataset. Interestingly, they are significantly lower than the Miocene values obtained in the southern Junggar by [15] and similar to the lowest values obtained for Pliocene samples in the same area. The corresponding carbon 
isotope compositions are also low (comparable to the lowest values reported by [17] from the Yili Basin) and significantly variable ( $-11.7 \%$ to $-6.8 \%$ ).

These peculiar isotopic compositions in the Canyon section remain difficult to explain especially since the Canyon section actually belongs to the Altai drainage system but no carbonate $\mathrm{O}$ and $\mathrm{C}$ isotope composition data are available from the Altai foothills along the eastern edge of the Junggar Basin (Figure 1). However, because a similar result is not observed in the contemporaneous samples of the southern Junggar, the driving mechanism must be local and not regional. First, the Canyon section was continuously situated within the central part of the basin and the low $\delta^{18} \mathrm{O}$ and $\delta^{13} \mathrm{C}$ values cannot be related to important changes in the altitude of the section. Secondly, a change towards $C 4$ type vegetation would only occur since the $\mathrm{C} 4$ plant appearance during the late Miocene (i.e., after the formation of the analyzed paleosols) $[27,35,36]$ and would increase the $\delta^{13} \mathrm{C}$ values without effect on $\delta^{18} \mathrm{O}$.

In the Yili Basin section, Reference [17] describe a progressive increase in both oxygen and carbon isotope compositions through the Oligocene-iocene transition (suggesting more arid conditions), associated with an increase in soil alteration (suggesting an increase in the ground water content). They explain their results through an increase in orographic precipitation on the growing Tian Shan Range as suggested by [97] and a correlative increased aridity in the Yili Basin. Following this model, most of the water available in the Yili Basin would be provided by rivers flowing from the uplifting Tian Shan range. As mentioned above, the Oligocene to early Miocene period is generally associated with an aridity increase in Central Asia (e.g., $[17,55,72,73])$. This period was also marked by the development of a wide lacustrine system in the Junggar Basin (Anjihai He and Taxi He formations) reaching the northern foothills of the Tian Shan and flooding most of the southern part of the basin $[15,91,98,99]$. The development of this lacustrine system fits with the increased orographic precipitation in the Tian Shan suggested by [97]. Such a large water body likely increased the local moisture and amount of ground and soil water, allowing more efficient soil respiration and thus a decrease in $\delta^{13} \mathrm{C}[31,32]$. Indeed, at depths of a few tens of centimeters, soil water includes meteoric water, infiltrated surface water (from rivers of lakes for example) and ground water during periods of high stand [100]. However, this mechanism alone does not explain the low $\delta^{18} \mathrm{O}$ values: because of evaporation, lake water would tend to have a higher $\delta^{18} \mathrm{O}$ value. Moreover, in semi-arid regions, soil carbonate precipitation occurs during the dry, high evaporation season, further increasing the $\delta^{18} \mathrm{O}$ of soil carbonates [22,27]. A generally wetter environment may decrease sub-cloud evaporation, which would decrease the $\delta^{18} \mathrm{O}$ of precipitation. However, as mentioned above, although large lakes were present, aridity increased during the late Paleoegene-early Miocene period. This discrepancy between enhanced lake-water evaporation driven by an arid climate and the observed low $\delta^{18} \mathrm{O}$ values could be partially solved by a constant renewing of the water body, implying water input from orographic precipitation in the Tian Shan and/or Altai and water output through a river system. Such a connection between the Junggar Basin and possibly the proto-Paratethys sea to the west is suggested by the occurrence of ray scales within Burdigalian sediments in the northern foothills of the Tian Shan [91].

Finally, a potential influence of river water derived from elevated regions in the Altai Range and showing low isotopic compositions could also be considered. However, no evidence of Oligocene to early Miocene relief building in the Altai has been reported (e.g., [44,53]). Based on stable isotope evidence and air-parcel back-trajectory modeling, $[29,61]$ concluded that relief building in Altai initiated during the late Miocene. Sections showing the same series exist further north of the Canyon section, closer to the Altai foothills (Dingshan and Tieersihabahe sections) [72,88-90], which should be explored to provide additional constraints to better understand these peculiar, low, $\mathrm{O}$ and $\mathrm{C}$ isotope values.

\subsection{Influence of Hypsometry on the Long-Term Isotopic Composition of Calcareous Paleosols in Central Asia}

Regardless of the persisting semi-arid to arid conditions, the calcareous paleosols of the Tian Shan region generally show a decrease in the $\delta^{18} \mathrm{O}$ values between the Cretaceous and the late Miocene-Pliocene (Figure $6 \mathrm{C}$ ). As detailed above, the only exceptions to this long-term trend 
are the late Oligocene-early Miocene data from Central Junggar. The lithologies supporting the sampled paleosols being consistently associated with alluvial plain depositional environments, the soil processes controlling the measured $\mathrm{C}$ and $\mathrm{O}$ isotope ratios must have been similar [15], except for short-time variations in soil respiration and water evaporation rates due to fluctuation in seasonality, mean temperature and mean amount of precipitation.

Changes in several other parameters could explain this decrease in the $\delta^{18} \mathrm{O}$ values: a variation in latitude, amount of precipitation, distance to the sea, elevation of the depositional area, or hypsometry of the drainage systems $[15,22-24,33]$. First, the latitude of the sections did not vary significantly since the Cretaceous (a northward shift of about $8^{\circ}$ since the Maastrichtian [101]). Second, even if the distance to the sea increased largely between the late Eocene and the Pliocene due to the retreat of the proto-Paratethys to the west (e.g., [10]), we have shown above that this parameter apparently had no recordable effect on the $\delta^{18} \mathrm{O}$ values in calcareous paleosols over distances of several hundreds of kilometers from the sea. Third, the altitudes of the various sections have varied through time due to the Neogene uplift of the Tian Shan Range. At present day, these altitudes are about $700 \mathrm{~m}$ for Tash Komyr and the central Junggar Canyon, about $1000 \mathrm{~m}$ for the southern Junggar, and up to about $1700 \mathrm{~m}$ for the Yaha section. The Tash Komyr section was at sea level during the Eocene and probably remained at low altitude throughout the Cretaceous-Paleogene. Variations in the mean altitude of the central Junggar basin linked to varying sediment accommodation rates are unconstrained, but the absence of marine deposits suggests that the surface of the basin remained above sea level since the Late Cretaceous, most probably to an altitude of a few hundred meters. The occurrence of a major lake system reaching the northern foothills of the range during the Oligocene to early Miocene indicates that at least during that period, the altitude of the southern Junggar sections was similar to the elevation of the central part of the basin $[98,102]$. The northern and southern Tian Shan foothills, including the southern Junggar and Yaha sections, have been affected by deformation since the Late Cretaceous $[91,103,104]$. Although late Oligocene-early Miocene reliefs have been suggested in the western part of the range (e.g., $[3,97,105])$, a large amount of the total uplift is related to the late Miocene increase in tectonic deformation [106]. These variations between the Late Cretaceous and present-day altitude of the sections could account for $\delta^{18} \mathrm{O}$ variations of less than $1 \%$ in the Tash Komyr, central Junggar Canyon and southern Junggar sections, and to a maximum of $3.5 \%$ in the Yaha section (considering a $2 \% \cdot \mathrm{km}^{-1}$ decrease in $\delta^{18} \mathrm{O}$ with altitude after [107]). However, except for the Yaha section, these variations in the isotopic composition remain inside the dispersion range of the data presented here and can thus be considered as negligible.

The semi-arid climate conditions prevailing during the Late Cretaceous in the Junggar Basin could probably be compared with the present-day conditions. Indeed, the average total annual precipitation ranges between 100 and $250 \mathrm{~mm}$ at present $[108,109]$, while it is estimated to have been less than $400 \mathrm{~mm}$ during the late Maastrichtian [110]. The rain shadow that developed during the late Miocene [29] did decrease the amount of precipitation in the basins, and this enhanced aridity should have increased both the $\delta^{18} \mathrm{O}$ and $\delta^{13} \mathrm{C}$ values. The decrease in $\delta^{18} \mathrm{O}$ values between Miocene and Pliocene samples from the South Junggar has been related to a change in hypsometry of the drainage systems in the northern Tian Shan Range due to the enhanced uplift and erosion of the pre-Miocene topography [15]. We acknowledge that it is commonly accepted that the $\delta^{18} \mathrm{O}$ values of soil carbonates rather reflects the $\delta^{18} \mathrm{O}$ values of local precipitation than that of surface flowing water or of ground-water (e.g., $[22,25,27,31])$. However, interaction between ground-water and soil water does exist, with the various ways ground-water can rise to the surface and mix with soil-water depending mostly on the topography (e.g., [111]). Reference [112] has shown, based on numerical modeling, that the water table can rise up to the vegetation root zone and increase evapotranspiration, reaching up to several $10 \%$ of the total value. Evidence for present-day artesian behavior of the phreatic aquifer in the slow slope region of the Junggar basin is attested in the literature [113], suggesting that in the central part of the basin, soil-water can be partially derived from ground-water. At present day, most of the ground water in the Junggar Basin is brought by rivers flowing from both the Tian Shan Range 
(southern part of the basin) and the Altai Range (central and northern parts of the basin) (Figure 1). As mentioned above, a similar situation most probably prevailed during the late Oligocene-Miocene and according to the facies shifts and paleocurrent measurements in the basin this must have been the case at least since the Late Cretaceous [114]. In the same way that [115] have suggested that the spread in the oxygen isotope composition observed in lacustrine and soil carbonate samples from the Himalayas may reflect mixing between precipitation at and above the sampling site, the semi-arid climate, implying low precipitations in the basin, suggests that the water of the Tian Shan and Altai rivers may have had a significant impact on the carbon and oxygen isotope ratios of pedogenic carbonates within the Junggar. A similar situation probably occurred in the Tarim and Fergana basins. The topography of the Tian Shan and Altai ranges is mainly related to their Neogene uplift [91] and we argue that the hypsometry of the drainage systems, through mixing between precipitation and run-off water, was a major factor controlling the oxygen isotope composition of the calcareous paleosols in the region surrounding the Tian Shan Range. Further analysis of Quaternary calcareous paleosols should verify this assumption by showing still lower $\delta^{18} \mathrm{O}$ values. Such a topographic effect could also explain the drop in $\delta^{18} \mathrm{O}$ values (associated with a decrease in $\delta^{13} \mathrm{C}$ values) observed at the Late Cretaceous-early Paleogene transition in the Tash Komyr section (Figure 2 and Table 1). Indeed, as explained above, while the Early Cretaceous topography remained largely flat [3,7], the Late Cretaceous-earlier Paleogene period was marked by tectonic activity leading to relief building along the major faults associated with the Tian Shan and Altai ranges [42-44,53,54,91].

\section{Conclusions}

The continuous occurrence of calcareous paleosols (caliches and calcretes) in the Cretaceous to Paleogene sediments of the northeastern Fergana, northern Tarim, and Junggar basins, indicate that this region has continuously been subjected to semi-arid, seasonal climate conditions, independent of the presence of the proto-Paratethys Sea. The distance to the sea has no measurable impact on the isotopic composition of the paleosols analyzed in this study. Although this conclusion should be tested further, the oxygen and carbon isotope composition of caliches and calcretes from Central Asia should thus not be used as indicators of the influence of the proto-Paratethys Sea on regional climate conditions. The overall decrease in $\delta^{18} \mathrm{O}$ values between the Upper Cretaceous-late Paleogene and the Neogene seems consistent with the uplift of the Central Asian ranges starting in the Oligocene and increasing in the late Miocene. Consequently, although it is commonly accepted that the $\delta^{18} \mathrm{O}$ values of soil carbonates are primarily governed by the $\delta^{18} \mathrm{O}$ values of local precipitation, we propose that the oxygen isotope composition of the calcareous paleosols within the Junggar Basin is partially governed by the isotopic composition of the river waters feeding the basin. Variations in $\delta^{18} \mathrm{O}$ thus reflect, at first order, the changes in hypsometry of the upstream drainage systems. As shown by the significantly lower $\delta^{18} \mathrm{O}$ and $\delta^{13} \mathrm{C}$ values obtained in the Oligocene to middle Miocene samples from the central Junggar Basin, local factors such as the occurrence of large water bodies mainly supplied by river water, also play a significant role in controlling the isotopic composition of calcareous paleosols.

Author Contributions: Conceptualization, M.J.; Methodology, M.J. and P.B.; Investigation, all co-authors; Writing-Original Draft Preparation, M.J. and P.B; Writing-Review \& Editing, All authors.

Funding: This research received no external funding.

Acknowledgments: We would like to thank the 5 anonymous reviewers and the scientific editor Ch. Lecuyer that provided useful comments to improve this manuscript.

Conflicts of Interest: The authors declare no conflict of interest.

\section{References}

1. Molnar, P.; Tapponnier, P. Cenozoic Tectonics of Asia: Effects of a continental Collision. Science 1975, 189, 419-426. [CrossRef] [PubMed] 
2. Avouac, J.P.; Tapponnier, P.; Bai, M.; You, H.; Wang, G. Active thrusting and folding along the northern Tien Shan and Late Cenozoic rotation of the Tarim relative to Dzungaria and Kazakhstan. J. Geophys. Res. 1993, 98, 6755-6804. [CrossRef]

3. De Grave, J.; Buslov, M.M.; Van den Haute, P. Distant effects of India-Eurasia convergence and Mesozoic intracontinental deformation in Central Asia: Constraints from apatite fission-track thermochronology. J. Asian Earth Sci. 2007, 29, 188-204. [CrossRef]

4. Jolivet, M. Mesozoic tectonic and topographic evolution of Central Asia and Tibet: A preliminary synthesis. In Geological Evolution of Central Asian Basins and the Western Tien Shan Range; Brunet, M.F., McCann, T., Sobel, E.R., Eds.; Geological Society of London Special Publications; Geological Society of London: London, UK, 2017; Volume 427.

5. Cunningham, D.; Owen, L.A.; Snee, L.W.; Li, J. Structural framework of a major intracontinental orogenic termination zone: The easternmost Tien Shan, China. J. Geol. Soc. Lond. 2003, 160, 575-590. [CrossRef]

6. Vassallo, R.; Jolivet, M.; Ritz, J.-F.; Braucher, R.; Larroque, C.; Sue, C.; Todbileg, M.; Javkhlanbold, D. Uplift age and rates of the Gurvan Bogd system (Gobi-Altay) by apatite fission track analysis. Earth Planet. Sci. Lett. 2007, 259, 333-346. [CrossRef]

7. Jolivet, M.; Heilbronn, G.; Robin, C.; Barrier, L.; Bourquin, S.; Guo, Z.; Jia, Y.; Guerit, L.; Yang, W.; Fu, B. Reconstructing the Late Palaeozoic-Mesozoic topographic evolution of the Chinese Tian Shan: Available data and remaining uncertainties. Adv. Geosci. 2013, 37,7-18. [CrossRef]

8. Ramstein, G.; Fluteau, F.; Besse, J.; Joussaume, S. Effect of orogeny, plate motion and land-sea distribution on Eurasian climate change over the past 30 million years. Nature 1997, 386, 788-795. [CrossRef]

9. Burtman, V.S. Cenozoic crustal shortening between the Pamir and Tien Shan and a reconstruction of the Pamir-Tien Shan transition zone for the Cretaceous and Palaeogene. Tectonophysics 2000, 319, 69-92. [CrossRef]

10. Bosboom, R.; Mandic, O.; Dupont-Nivet, G.; Proust, J.-N.; Ormukov, C.; Aminov, J. Late Eocene palaeogeography of the proto-Paratethys Sea in Central Asia (NW China, southern Kyrgyzstan and SW Tajikistan). In Geological Evolution of Central Asian Basins and the Western Tien Shan Range; Brunet, M.F., McCann, T., Sobel, E.R., Eds.; Geological Society of London Special Publications; Geological Society of London: London, UK, 2017; Volume 427.

11. Sobel, E.R. Basin analysis of the Jurassic_Lower Cretaceous southwest Tarim basin, northwest China. Geol. Soc. Am. Bull. 1999, 111, 709-724. [CrossRef]

12. Bershaw, J.; Garzione, C.N.; Schoenbohm, L.; Gehrels, G.; Li, T. Cenozoic evolution of the Pamir plateau based on stratigraphy, zircon provenance, and stable isotopes of foreland basin sediments at Oytag (Wuyitake) in the Tarim Basin (West China). J. Asian Earth Sci. 2012, 44, 136-148. [CrossRef]

13. Dupont-Nivet, G.; Krijgsman, W.; Langereis, C.G.; Abels, H.A.; Dai, S.; Fang, X. Tibetan plateau aridification linked to global cooling at the Eocene-Oligocene transition. Nature 2007, 445, 635-638. [CrossRef] [PubMed]

14. Licht, A.; van Cappelle, M.; Abels, H.A.; Ladant, J.-B.; Trabucho-Alexandre, J.; France-Lanord, C.; Donnadieu, Y.; Vandenberghe, J.; Rigaudier, T.; Lécuyer, C.; et al. Asian monsoons in a late Eocene greenhouse world. Nature 2014, 513. [CrossRef] [PubMed]

15. Charreau, J.; Kent-Corson, M.L.; Barrier, L.; Augier, R.; Ritts, B.D.; Chen, Y.; France-Lannord, C.; Guilmette, C. A high-resolution stable isotopic record from the Junggar Basin (NW China): Implications for the paleotopographic evolution of the Tianshan Mountains. Earth Planet. Sci. Lett. 2012, 341-344, 158-169. [CrossRef]

16. Heilbronn, G.; Boulvais, P.; Marchand, E.; Robin, C.; Bourquin, S.; Barrier, L.; Jia, Y.; Fu, B.; Jolivet, M. Stable isotope characterization of pedogenic and lacustrine carbonates from the Chinese Tian Shan: Constraints on the Mesozoic_Lower Cenozoic paleo-environmental evolution. Chemie der Erde 2015, 75, 133-141. [CrossRef]

17. Bougeois, L.; de Rafélis, M.; Reichart, G.-J.; de Nooijer, L.J.; Nicollin, F.; Dupont-Nivet, G. A high resolution study of trace elements and stable isotopes in oyster shells to estimate Central Asian Middle Eocene seasonality. Chem. Geol. 2014, 363, 200-212. [CrossRef]

18. Hellwig, A.; Voigt, S.; Mulch, A.; Frisch, K.; Bartenstein, A.; Pross, J.; Gerdes, A.; Voigt, T. Late Oligocene to early Miocene humidity change recorded in terrestrial sequences in the Ili Basin (south-eastern Kazakhstan, Central Asia). Sedimentol 2018, 65, 517-539. [CrossRef]

19. Jenny, H. The Soil Resource: Origin and Behavior; Springer: Berlin, Germany, 1980; ISBN 978-1-4612-6112-4.

20. Retallack, G.J. A Colour Guide to Paleosols; John Wiley and Sons Ltd.: Chichester, UK, 1997. 
21. Birkeland, P.W. Soils and Geomorphology; Oxford University Press: New York, NY, USA, 1999; ISBN 9780195078862.

22. Cerling, T.E.; Quade, J. Stable Carbon and Oxygen Isotopes in Soil Carbonates. In Climate Change in Continental Isotopic Records; Geophysical Monograph; American Geophysical Union: Washington, DC, USA, 1993; Volume 78, pp. 217-231.

23. Rozanski, K.; Araguas-Aragueas, L.; Gonfiantini, R. Isotopic patterns in modern global precipitation. In Climate Change in Continental Isotopic Records; Swart, P.K., Lohmann, K.C., McKenzie, J., Savin, S., Eds.; Geophysical Monograph Series; American Geophysical Union: Washington, DC, USA, 1993; Volume 78, pp. 1-36.

24. Winnick, M.J.; Chamberlain, C.P.; Caves, J.K.; Welker, J.M. Quantifying the isotopic 'continental effect'. Earth Planet. Sci. Lett. 2014, 406, 123-133. [CrossRef]

25. Allison, G.B.; Barnes, C.J.; Hughes, M.W.; Leary, F.W.J. The effect of climate and vegetation on the oxygen-18 and deuterium profiles in soils. In Isotope Hydrology 1983; International Atomic Energy Agency: Vienna, Austria, 1984; pp. 105-123.

26. Cerling, T.E. Carbon dioxide in the atmosphere: Evidence from Cenozoic and Mesozoic paleosols. Am. J. Sci. 1991, 291, 377-400. [CrossRef]

27. Quade, J.; Cerling, T.E.; Bowman, J.R. Systematic variations in the stable carbon and oxygen isotopic composition of pedogenic carbonate along elevation transects in the southern Great Basin, USA. Geol. Soc. Am. Bull. 1989, 101, 464-475. [CrossRef]

28. Körner, C.; Farquhar, G.; Wong, S.C. Carbon isotope discrimination by plants follows latitudinal and altitudinal trends. Oecologia 1991, 88, 30-40. [CrossRef] [PubMed]

29. Caves, J.K.; Bayshashov, B.U.; Zhamangara, A.; Ritch, A.J.; Ibarra, D.E.; Sjostrom, D.J.; Mix, H.T.; Winnick, M.J.; Chamberlain, C.P. Late Miocene Uplift of the Tian Shan and Altai and Reorganization of Central Asia Climate. GSA Today 2016, 27. [CrossRef]

30. Oerter, E.J.; Amundson, R. Climate controls on spatial and temporal variations in the formation of pedogenic carbonate in the western Great Basin of North America. Geol. Soc. Am. Bull. 2016. [CrossRef]

31. Cerling, T.E. The stable isotopic composition of modern soil carbonate and its relationship to climate. Earth Planet. Sci. Lett. 1984, 71, 229-240. [CrossRef]

32. Kohn, M.J. Carbon isotope compositions of terrestrial C3 plants as indicators of (paleo)ecology and (paleo)climate. Proc. Natl. Acad. Sci. USA 2010, 107, 19691-19695. [CrossRef] [PubMed]

33. Retallack, G.J. Pedogenic carbonate proxies for amount and seasonality of precipitation in paleosols. Geology 2005, 33, 333-336. [CrossRef]

34. O'Leary, H. Carbon isotope fractionation in plants. Phytochemistry 1981, 20, 553-567. [CrossRef]

35. Quade, J.; Cerling, T.E. Expansion of C4 grasses in the Late Miocene of northern Pakistan: Evidence from stable isotopes of paleosols. Palaeogeogr. Palaeoclimatol. Palaeoecol. 1995, 115, 91-116. [CrossRef]

36. Sanyal, P.; Bhattacharya, S.K.; Kumar, R.; Ghosh, S.K.; Sangode, S.J. Mio-Pliocene monsoonal record from Himalayan foreland basin (Indian Siwalik) and its relation to the vegetational change. Palaeogeogr. Palaeoclimatol. Palaeoecol. 2004, 205, 23-41. [CrossRef]

37. Strömberg, C.A.E. Evolution of Grasses and Grassland Ecosystems. Annu. Rev. Earth Planet. Sci. 2011, 39, 517-544. [CrossRef]

38. Still, C.J.; Berry, J.A.; Collatz, G.J.; DeFries, R.S. Global distribution of C-3 and C-4 vegetation: Carbon cycle implications. Glob. Biogeochem. Cycles 2003, 17, 1-14. [CrossRef]

39. Karamysheva, Z.V.; Rachkovskaya, E.I. Botanical Geography of the Steppe Part of Central Kazakhstan (Botanicheskaya Geografia Stepnoy Chasti Tsentralnogo Kazakhstana); The Steppe: Leningrad, Russia, 1973; 278p.

40. Windley, B.F.; Alexeiev, D.; Xiao, W.; Kröner, A.; Badarch, G. Tectonic models for accretion of the Central Asian Orogenic Belt. J. Geol. Soc. Lond. 2007, 164, 31-47. [CrossRef]

41. Allen, M.B.; Windley, B.F.; Zhang, C.; Zhao, Z.Y.; Wang, G.R. Basin evolution within and adjacent to the Tienshan range, NW China. J. Geol. Soc. Lond. 1991, 148, 369-378. [CrossRef]

42. Dumitru, T.A.; Zhou, D.; Chang, E.Z.; Graham, S.A. Uplift, exhumation, and deformation in the Chinese Tian Shan. Geol. Soc. Am. Mem. 2001, 194, 71-99.

43. Jolivet, M.; Dominguez, S.; Charreau, J.; Chen, Y.; Li, Y.; Wang, Q. Mesozoic and Cenozoic tectonic history of the Central Chinese Tian Shan: Reactivated tectonic structures and active deformation. Tectonics 2010, 29, TC6019. [CrossRef] 
44. Glorie, S.; De Grave, J.; Delvaux, D.; Buslov, M.M.; Zhimulev, F.I.; Vanhaecke, F.; Elburg, M.A.; Van den haute, P. Tectonic history of the Irtysh shear zone (NE Kazakhstan): New constraints from zircon U/Pb dating, apatite fission track dating and palaeostress analysis. J. Asian Earth Sci. 2012, 45, 138-149. [CrossRef]

45. Bullen, M.E.; Burbank, D.W.; Garver, J.I.; Abdrakhmatov, K.Y. Late Cenozoic tectonic evolution of the northwestern Tien Shan: New age estimate for the initiation of mountain building. Geol. Soc. Am. Bull. 2001, 113, 1544-1559. [CrossRef]

46. Jolivet, M.; Ritz, J.-F.; Vassallo, R.; Larroque, C.; Braucher, R.; Todbileg, M.; Chauvet, A.; Sue, C.; Arnaud, N.; De Vicente, R.; et al. The Mongolian summits: An uplifted, flat, old but still preserved erosion surface. Geology 2007, 35, 871-874. [CrossRef]

47. De Grave, J.; Van den Haute, P. Denudation and cooling of the Lake Teletskoye Region in the Altai Mountains (South Siberia) as revealed by apatite fission-track thermochronology. Tectonophysics 2002, 349, 145-159. [CrossRef]

48. Glorie, S.; De Grave, J.; Buslov, M.M.; Elburg, M.A.; Stockli, D.F.; Gerdes, A.; Van den haute, P. Multi-method chronometric constraints on the evolution of the Northern Kyrgyz Tien Shan batholith (Central Asian Orogenic Belt): From emplacement to exhumation. J. Asian Earth Sci. 2010, 38, 131-146. [CrossRef]

49. Hendrix, M.; Graham, S.A.; Carroll, A.; Sobel, E.; McKnight, C.; Schulein, B.; Wang, Z. Sedimentary record and climatic implications of recurrent deformation in the Tian Shan: Evidence from Mesozoic strata of the north Tarim, south Dzungar, and Turpan basin, northwest China. Geol. Soc. Am. Bull. 1992, 104, 53-79. [CrossRef]

50. Eberth, D.A.; Brinkman, D.B.; Chen, P.-J.; Yuan, F.-T.; Wu, Z.; Li, G.; Cheng, X.-S. Sequence stratigraphy, paleoclimate patterns, and vertebrate fossil preservation in Jurassic-Cretaceous strata of the Junggar Basin, Xinjiang Autonomous Region, People's Republic of China. Can. J. Earth Sci. 2001, 38, 1627-1644.

51. Yang, W.; Jolivet, M.; Dupont-Nivet, G.; Guo, Z.; Zhang, Z.; Wu, C. Source to sink relations between the Tian Shan and Junggar basin (northwest China) from Late Palaeozoic to Quaternary: Evidence from detrital U-Pb zircon geochronology. Basin Res. 2013, 25, 219-240. [CrossRef]

52. Jolivet, M.; Bourquin, S.; Heilbronn, G.; Robin, C.; Barrier, L.; Dabard, M.-P.; Jia, Y.; De Pelsmaeker, E.; Fu, B. The Upper-Jurassic-Lower Cretaceous Alluvial-Fan Deposits of the Kalaza Formation (Central Asia): Tectonic Pulse or Increased Aridity? Geological Society of London Special Publications; Geological Society of London: London, UK, 2017; Volume 427.

53. Yuan, W.; Carter, A.; Dong, J.; Bao, Z.; An, Y.; Guo, Z. Mesozoic-Tertiary exhumation history of the Altai Mountains, northern Xinjiang, China: Constraints from apatite fission track data. Tectonophysics 2006, 412, 183-193. [CrossRef]

54. De Grave, J.; Glorie, S.; Buslov, M.M.; Stockli, D.F.; McWilliams, M.O.; Batalev, V.Y.; Van den haute, P. Thermo-tectonic history of the Issyk-Kul basement (Kyrgyz Northern Tien Shan, Central Asia). Gondwana Res. 2013, 23, 998-1020. [CrossRef]

55. Blayney, T.; Najman, Y.; Dupont-Nivet, G.; Carter, A.; Millar, I.; Garzanti, E.; Sobel, E.R.; Rittner, M.; Ando, S.; Guo, Z.; et al. Indentation of the Pamirs with respect to the northern margin of Tibet: Constraints from the Tarim basin sedimentary record. Tectonics 2016, 35, 2345-2369. [CrossRef]

56. Bande, A.; Radjabov, S.; Sobel, E.R.; Sim, T. Cenozoic Palaeoenvironmental and Tectonic Controls on the Evolution of the Northern Fergana Basin; Geological Society of London Special Publications; Geological Society of London: London, UK, 2017; Volume 427.

57. Allen, M.B.; Windley, B.F.; Zhang, C. Cenozoic tectonics in the Urumqi-Korla region of the Chinese Tien Shan. Geol. Rundsch. 1994, 83, 406-416.

58. Jia, Y.; Fu, B.; Jolivet, M.; Zheng, S. Cenozoic tectono-geomorphological growth of the SW Chinese Tian Shan: Insight from AFT and detrital zircon U-Pb data. J. Asian Earth Sci. 2015, 111, 395-413. [CrossRef]

59. Yang, W.; Dupont-Nivet, G.; Jolivet, M.; Guo, Z.; Bougeois, L.; Bosboom, R.; Zhang, Z.; Heilbronn, G. Magnetostratigraphic record of the early evolution of the southwestern Tian Shan foreland basin (Ulugqat area), interaction with Pamir indentation and India-Asia collision. Tectonophysics 2015, 644-645, 122-137. [CrossRef]

60. Cunningham, W.D.; Windley, B.F.; Dorjnamjaa, D.; Badamgarov, J.; Saandar, M. Late Cenozoic transpression in southwestern Mongolia and the Gobi Altai-Tien Shan connection. Earth Planet. Sci. Lett. 1996, 140, 67-81. [CrossRef] 
61. Caves, J.K.; Sjostrom, D.J.; Mix, H.T.; Winnick, M.J.; Chamberlain, C.P. Aridification of Central Asia and uplift of the Altai and Hangay Mountains, Mongolia: Stable isotope evidence. Am. J. Sci. 2014, 314, 1171-1201. [CrossRef]

62. Ashraf, A.R.; Sun, Y.; Sun, G.; Uhl, D.; Mosbrugger, V.; Li, J.; Herrmann, M. Triassic and Jurassic palaeoclimate development in the Junggar Basin, Xinjiang, Northwest China a review and additional lithological data. Palaeobiol. Palaeoenviron. 2010, 90, 187-201. [CrossRef]

63. Tang, F.; Luo, Z.X.; Zhou, Z.H.; You, H.L.; Georgi, J.A.; Tang, Z.L.; Wang, X.Z. Biostratigraphy and palaeoenvironment of the dinosaur-bearing sediments in Lower Cretaceous of Mazongshan area, Gansu Province, China. Cretac. Res. 2001, 22, 115-129. [CrossRef]

64. De Pelsmaeker, E.; Jolivet, M.; Dransart Laborde, A.; Poujol, M.; Robin, C.; Zhimulev, F.I.; Nachtergaele, S.; Glorie, S.; De Clercq, S.; Batalev, V.Y.; et al. Source-to-sink relations in the Kyrgyz Tien Shan from the Jurassic to the Paleogene: Insights from sedimentological and detrital zircon U-Pb analyses. Gondwana Res. 2018, 54, 180-204. [CrossRef]

65. Hasegawa, T. Cretaceous terrestrial paleoenvironments of northeastern Asia suggested from carbon isotope stratigraphy: Increased atmospheric ${ }_{p} \mathrm{CO}_{2}$-induced climate. J. Asian Earth Sci. 2003, 21, 849-859. [CrossRef]

66. Morris, F.K. Central Asia in Cretaceous time. Geol. Soc. Am. Bull. 1936, 47, 1477-1534. [CrossRef]

67. Currie, P.J.; Eberth, D.A. Palaeontology, sedimentology and palaeoecology of the Iren Dabasu Formation (Upper Cretaceous), Inner Mongolia, People's Republic of China. Cretac. Res. 1993, 14, 127-144. [CrossRef]

68. Abels, H.A.; Dupont-Nivet, G.; Xiao, G.; Bosboom, R.; Krijgsman, W. Step-wise change of Asian interior climate preceding the Eocene-Oligocene Transition (EOT). Palaeogeogr. Palaeoclimatol. Palaeoecol. 2011, 299, 399-412. [CrossRef]

69. Zhang, Z.; Flatøy, F.; Wang, H.; Bethke, I.; Bentsen, M.; Guo, Z. Early Eocene Asian climate dominated by desert and steppe with limited monsoons. J. Asian Earth Sci. 2012, 44, 24-35. [CrossRef]

70. Zheng, H.; Wei, X.; Tada, R.; Clift, P.D.; Wang, B.; Jourdan, F.; Wang, P.; He, M. Late Oligocene-early Miocene birth of the Taklimakan Desert. Proc. Natl. Acad. Sci. USA 2015, 112, 7662-7667. [CrossRef] [PubMed]

71. Sun, D.; Bloemendal, J.; Yi, Z.; Zhu, Y.; Wang, X.; Zhang, Y.; Li, Z.; Wang, F.; Han, F.; Zhang, Y. Palaeomagnetic and palaeoenvironmental study of two paralell sections of the late Cenozoic strata in the central Taklimakan Desert: Implications for the desertification of the Tarim Basin. Palaeogeogr. Palaeoclimatol. Palaeoecol. 2011, 300, 1-10. [CrossRef]

72. Guo, Z.T.; Ruddiman, W.F.; Hao, Q.Z.; Wu, H.B.; Qiao, Y.S.; Zhu, R.X.; Peng, S.Z.; Wei, J.J.; Yuan, B.Y.; Liu, T.S. Onset of Asian desertification by 22 My ago inferred from loess deposits in China. Nature 2002, 416, 159-163. [CrossRef] [PubMed]

73. Sun, J.; Ye, J.; Wu, W.; Ni, X.; Bi, S.; Zhang, Z.; Liu, W.; Meng, J. Late Oligocene-Miocene mid-latitude aridification and wind patterns in the Asian interior. Geology 2010, 38, 515-518. [CrossRef]

74. Sun, J.; Windley, B.F. Onset of aridification by $34 \mathrm{Ma}$ across the Eocene-Oligocene transition in Central Asia. Geology 2015, 43, 1015-1018. [CrossRef]

75. Harzhauser, M.; Daxner-Höck, G.; Lopez-Guerrero, P.; Maridet, O.; Oliver, A.; Piller, W.E.; Richoz, S.; Erbajeva, M.A.; Neubauer, T.A.; Göhlich, U.B. Stepwise onset of the Icehouse world and its impact on Oligo-Miocene Central Asian mammals. Sci. Rep. 2016, 6, 36169. [CrossRef] [PubMed]

76. Schiemann, R.; Lüthi, D.; Vidale, P.L.; Schär, C. The precipitation climate of Central Asia-Intercomparison of observational and numerical data sources in a remote semiarid region. Int. J. Climatol. 2008, 28, 295-314. [CrossRef]

77. Schiemann, R.; Lüthi, D.; Schär, C. Seasonality and interannual variability of the westerly jet in the Tibetan Plateau region. J. Clim. 2009, 22, 2940-2957. [CrossRef]

78. Baldwin, J.; Vecchi, G. Influence of the Tianshan Mountains on arid extratropical Asia. J. Clim. 2016, 29, 5741-5762. [CrossRef]

79. Micheels, A.; Bruch, A.A.; Eronen, J.; Fortelius, M.; Harzhauser, M.; Utescher, T.; Mosbrugger, V. Analysis of heat transport mechanisms from a Late Miocene model experiment with a fully coupled atmosphere-ocean general circulation model. Palaeogeogr. Palaeoclimatol. Palaeoecol. 2011, 304, 337-350. [CrossRef]

80. Breeker, D.O.; Sharp, Z.D.; McFadden, L.D. Seasonal bia in the formation and stable isotopic composition of pedogenic carbonates in modern soils from central New Mexico, USA. Geol. Soc. Am. Bull. 2009, 121, 630-640. [CrossRef] 
81. Davis, S.J.; Mix, H.T.; Wiegand, B.A.; Carroll, A.R.; Chamberlain, C.P. Synorogenic evolution of large-scale drainage patterns: Isotope paleohydrology of sequential Laramide basins. Am. J. Sci. 2009, 309, 549-602. [CrossRef]

82. Horton, T.W.; Defliese, W.F.; Tripati, A.K.; Oze, C. Evaporation induced $18 \mathrm{O}$ and $13 \mathrm{C}$ enrichment in lake systems: A global perspective on hydrologic balance effects. Quat. Sci. Rev. 2016, 131, 365-379. [CrossRef]

83. Garzione, C.N.; Dettman, D.L.; Horton, B.K. Carbonate oxygen isotope paleoaltimetry: Evaluating the effect of diagenesis on paleoelevation estimates for the Tibetan plateau. Palaeogeogr. Palaeoclimatol. Palaeoecol. 2004, 212, 119-140. [CrossRef]

84. Aliev, M.M.; Genkina, R.Z.; Dubrovskaya, E.N.; Nikishova, V.M. Jurassic Continental Deposits of the East Middle Asia (Data, Dismemberment, Correlation); Nauka: Moscow, Russia, 1981; 188p. (In Russian)

85. Poyarkova, Z.N. Cretaceous system. In Geology of the USSR; Pomazkov, K.D., Ed.; Geology of Kyrgyz SSR; Nedra: Moscow, Russia, 1972; Volume 25, pp. 224-236. (In Russian)

86. Artyomova, Z.P.; Brodskiy, I.L.; Vnuchkov, V.I. Geological Map of the USSR; Aal-Kokshaal Series; Sheet K-43-XXV. 1:200,000; Geographicus Rare Antique Maps: Brooklyn, NY, USA, 1971. (In Russian)

87. Vialov, O.S. Paleogenovie Ustrici Tadzhikskoi Depressii (Paleogene Ostreids from Tajik Depression); Trudy VNIGRI: Leningrad, Russia, 1948.

88. Zhang, R.; Yue, L.-P.; Wang, J.-Q. Magnetostratigraphic dating of mammalian fossils in Junggar Basin, northwest China. Chin. Sci. Bull. 2007, 52, 1526-1531. [CrossRef]

89. Meng, J.; Ye, J.; Wu, W.-Y.; Ni, X.-J.; Bi, S.-D. The Neogene Dingshanyanchi Formation in northern Junggar Basin of Xinjiang and its stratigraphic implications. Vertebrata PalAsiatica 2008, 46, 90-110.

90. Wu, W.-Y.; Meng, J.; Ye, J.; Ni, X.-J.; Bi, S.-D.; Wei, Y.-P. The Miocene mammals from Dingshanyanchi Formation of North Junggar Basin, Xinjiang. Vertebrata PalAsiatica 2009, 47, 208-233.

91. Jolivet, M.; Barrier, L.; Dauteuil, O.; Laborde, A.; Li, Q.; Reichenbacher, B.; Popescu, S.-M.; Sha, J.; Guo, Z. New geomorphic and sedimentary insights into the Late Cretaceous-Paleogene topography of the Chinese Tian Shan. Earth Planet. Sci. Lett. 2018, 499, 95-106. [CrossRef]

92. Wang, Q.; Li, S.; Du, Z. Differential uplift of the Chinese Tianshan since the Cretaceous: Constraints from sedimentary petrography and apatite fission-track dating. Int. J. Earth Sci. 2009, 98, 1341-1363. [CrossRef]

93. Jin, Z.; Yang, M.; Lu, X.; Sun, D.; Tang, X.; Peng, G.; Lei, G. The tectonic and petroleum system of the Qiulitagh fold and thrust belt, northern Tarim basin, NW China. Mar. Petrol. Geol. 2008, 25, 767-777. [CrossRef]

94. Peng, S.; Li, Z.; Huang, B.; Liu, T.; Wang, Q. Magnetostratigraphic study of Cretaceous depositional succession in the northern Kuqa Depression, Northwest China. Chin. Sci. Bull. 2006, 51, 97-107. [CrossRef]

95. Huang, B.; Piper, J.D.A.; Peng, S.; Liu, T.; Li, Z.; Wang, Q.; Zhu, R. Magnetostratigraphic study of the Kuche Depression, Tarim Basin, and Cenozoic uplift of the Tian Shan Range, Western China. Earth Planet. Sci. Lett. 2006, 251, 346-364. [CrossRef]

96. Caves, J.K.; Winnick, M.J.; Graham, S.A.; Sjostrom, D.J.; Mulch, A.; Chamberlain, C.P. Role of the westerlies in Central Asia climate over the Cenozoic. Earth Planet. Sci. Lett. 2015, 428, 33-43. [CrossRef]

97. Macaulay, E.A.; Sobel, E.R.; Mikolaichuk, A.; Wack, M.; Gilder, S.A.; Mulch, A.; Fortuna, A.B.; Hynek, S.; Apayarov, F. The sedimentary record of the Issyk Kul basin, Kyrgyzstan: Climatic and tectonic inferences. Basin Res. 2016, 28, 57-80. [CrossRef]

98. Charreau, J.; Chen, Y.; Gilder, S.; Barrier, L.; Dominguez, S.; Augier, R.; Sen, S.; Avouac, J.-P.; Gallaud, A.; Graveleau, F; et al. Neogene uplift of the Tian Shan Mountains observed in the magnetic record of the Jingou River section (northwest China). Tectonics 2009, 28, TC2008. [CrossRef]

99. Yang, W.; Spiro, B.; Guo, Z.; Pentecost, A. Cenozoic lacustrine stromatolites from the southern margin of the Junggar Basin, NW China and adjacent areas: Indicators for palaeoclimatic and tectonic evolution. Geol. J. 2016. [CrossRef]

100. Fox, D.L.; Honey, J.G.; Martin, R.A.; Peláez-Campomanes, P. Pedogenic carbonate stable isotope record of environmental change during the Neogene in the southern Great Plains, southwest Kansas, USA: Oxygen isotopes and paleoclimate during the evolution of C4-dominated grassland. Geol. Soc. Am. Bull. 2012, 124, 431-443. [CrossRef]

101. Barrier, E.; Vrielynck, B.; Brouillet, J.-F.; Brunet, M.-F. Paleotectonic Reconstruction of the Central Tethyan Realm; Commission for the Geological Map of the World: Paris, France, 2018. 
102. Ji, J.; Luo, P.; White, P.; Jiang, H.; Gao, L.; Ding, Z. Episodic uplift of the Tianshan Mountains since the late Oligocene constrained by magnetostratigraphy of the Jingou River section, in the southern margin of the Junggar Basin, China. J. Geophys. Res. 2008, 113, B05102. [CrossRef]

103. Hendrix, M.S.; Dumitru, T.A.; Graham, S.A. Late Oligocene-early Miocene unroofing in the Chinese Tian Shan: An early effect of the India-Asia collision. Geology 1994, 22, 487-490. [CrossRef]

104. Sun, J.; Zhu, R.; Bowler, J. Timing of the Tianshan Mountains uplift constrained by magnetostratigraphic analysis of molasse deposits. Earth Planet. Sci. Lett. 2004, 219, 239-253. [CrossRef]

105. Macaulay, E.A.; Sobel, E.R.; Mikolaichuk, A.; Kohn, B.; Stuart, F.M. Cenozoic deformation and exhumation history of the Central Kyrgyz Tien Shan. Tectonics 2014. [CrossRef]

106. Charreau, J.; Gilder, S.; Chen, Y.; Dominguez, S.; Avouac, J.-P.; Sen, S.; Jolivet, M.; Li, Y.; Wang, W.M. Late Cenozoic erosion history of the Tianshan Mountains as recorded in the Yaha section, Tarim Basin, China. Geology 2006, 34, 181-184. [CrossRef]

107. Poage, M.A.; Chamberlain, C.P. Empirical relationships between elevation and the stable isotope composition of precipitation and surface waters: Considerations for studies of paleoelevation change. Am. J. Sci. 2001, 901, 1-18. [CrossRef]

108. Li, C.X.; Guo, Z.; Dupont-Nivet, G. Late Cenozoic tectonic deformation across the northern foreland of the Chinese Tian Shan. J. Asian Earth Sci. 2011, 42, 1066-1073. [CrossRef]

109. Chen, Y. Water Resources Research in Northwest China; Springer Science + Business Media: Dordrecht, The Netherlands, 2014.

110. Chen, J.; Zhao, P.; Wang, C.; Huang, Y.; Cao, K. Modeling East Asian climate and impacts of atmospheric $\mathrm{CO}_{2}$ concentration during the Late Cretaceous (66 Ma). Palaeogeogr. Palaeoclimatol. Palaeoecol. 2013, 385, 190-201. [CrossRef]

111. Winter, C.T. The concept of hydrologic landscape. J. Am. Water Res. Assoc. 2001, 37, 335-349. [CrossRef]

112. Gutowski, W.J., Jr. A Coupled Land-Atmosphere Simulation Program (CLASP): Calibration and validation. J. Geophys. Res. 2002, 107, ACL 3-1-ACL 3-17. [CrossRef]

113. Jia, R.; Zhou, J.; Zhou, Y.; Li, Q.; Gao, Y. A vulnerability evaluation of the phreatic water in the plain area of the Junggar Basin, Xinjiang based on the VDEAL model. Sustainability 2014, 6, 8604-8617. [CrossRef]

114. Bian, W.; Hornung, J.; Liu, Z.; Wang, P.; Hinderer, M. Sedimentary and palaeoenvironmental evolution of the Junggar Basin, Xinjiang, Northwest China. Palaeobiol. Palaeoenviron. 2010, 90, 175-186. [CrossRef]

115. Rowley, D.B.; Pierrehumbert, R.T.; Currie, B.S. A new approach to stable isotope-based paleoaltimetry: Implications for paleoaltimetry and paleohypsometry of the High Himalaya since the Late Miocene. Earth Planet. Sci. Lett. 2001, 188, 253-268. [CrossRef] 